\title{
Seismic structure of the northwestern margin of the South China Sea: implication for asymmetric continental extension
}

\author{
Haibo Huang, ${ }^{1}$ Xuelin Qiu, ${ }^{1,5}$ Thibaud Pichot, ${ }^{2}$ Frauke Klingelhoefer, ${ }^{3}$ Minghui Zhao, ${ }^{1,5}$ \\ Ping Wang ${ }^{1}$ and Tianyao $\mathrm{Hao}^{4,5}$ \\ ${ }^{1}$ Key Laboratory of Ocean and Marginal Sea Geology, South China Sea Institute of Oceanology, Chinese Academy of Sciences, Guangzhou 510301, China. \\ E-mail: xlqiu@scsio.ac.cn \\ ${ }^{2}$ Beicip-Franlab, 232 avenue Napoléon Bonaparte Rueil-Malmaison, Paris 92500, France \\ ${ }^{3}$ Department of Marine Geosciences, IFREMER, Brest 29280, France \\ ${ }^{4}$ Key Laboratory of Petroleum Resources Research, Institute of Geology and Geophysics, Chinese Academy of Sciences, Beijing 100029, China \\ ${ }^{5}$ College of Earth and Planetary Sciences, University of Chinese Academy of Sciences, Beijing 100049, China.
}

Accepted 2019 May 12. Received 2019 May 6; in original form 2019 January 27

\begin{abstract}
S UMMAR Y
Evolution of the continental margins of the South China Sea (SCS) is one of the open questions when discussing continental breakup and seafloor spreading. We processed data from a wide-angle seismic profile (OBS2011-1), which passes through the northwestern margin of the SCS, and performed travel time modelling to obtain the seismic velocity structures. The modelling results show a stepwise variation of the crustal thicknesses from continental margin to oceanic basin. Stretching factor of the upper crust is nearly double the estimate of the lower crust along the Zhongsha Trough. The lower crust shows asymmetrical upwelling towards the trough center, accompanied by $\sim 0.3 \mathrm{~km} \mathrm{~s}^{-1}$ of the velocity increase due to magmatic addition. The upper and lower crusts have almost the same stretching factor beneath continental blocks, indicating a uniform extension. Crustal structures of the conjugate margins of the Southwest Subbasin show similar velocity range and different thickness distribution, supporting the common origin and asymmetric extension of these two margins. The Ocean-Continent Transition zones (OCT) are much wider in the southern part $(\sim 50 \mathrm{~km})$ than the northern part $(\sim 25 \mathrm{~km})$ crossing the margins. We propose a tectonic model for the asymmetry of both the conjugate margins and the OCTs, favoring the highly stretched upper crust and accompanied by rising of the ductile middle-lower crust controlled by major low-angle faults. The rigid blocks may also act as a kind of hindrance for further evolution of the failed rifts and affect the shape of the OCT.
\end{abstract}

Key words: Seismic tomography; Continental tectonics: extensional; Crustal structure; Rheology: crust and lithosphere.

\section{INTRODUCTION}

The South China Sea (SCS) is a natural laboratory for studying rifting processes and mechanism of the continental extension (Nissen et al. 1995). Sandwiched by the Indian-Australian, Eurasian and Pacific Plate, the SCS evolved into a V-shaped basin bordered by wide rifted margins (Fig. 1). Among these, the northern margin has developed a broad thinned continental crust with an irregular topography corresponding to various tectonic units (Hayers \& Nissen 2005). A distinct high velocity layer (HVL) has been revealed at the bottom crust by refraction seismic surveys (Yan et al. 2001; Wei et al. 2011), restricted to slope areas in the NE margin. In comparison, existence of the HVL in the NW margin has long been controversial since wide-angle seismic modelling reported no such finding (Qiu et al. 2001; Ding et al. 2012; Wu et al. 2011), while a few seismic surveys and gravity modelling revealed scattered thin HVL (Qiu et al. 2013; Pichot et al. 2014). The transverse discrepant crustal structures along the northern margin were suggested to be associated with the progressive continental rifting and opening of the SCS (Zhou et al. 1995). Wu et al. (2005) considered the NE margin as the upper-plate in the simple-shear rifting model (Lister et al. 1986), and suggested that the HVL originated from asthenospheric underplating. As analog and numerical models show (Huismans et al. 2014), continental extension is in general depth-related and strongly depends on interstratified decoupling, which is also proven by detailed geophysical data of the SCS (Franke et al. 2014; Li et al. 2014b). To complicate matters, deep structures detected along several margins are also dependent on initial settings of rifting, such 


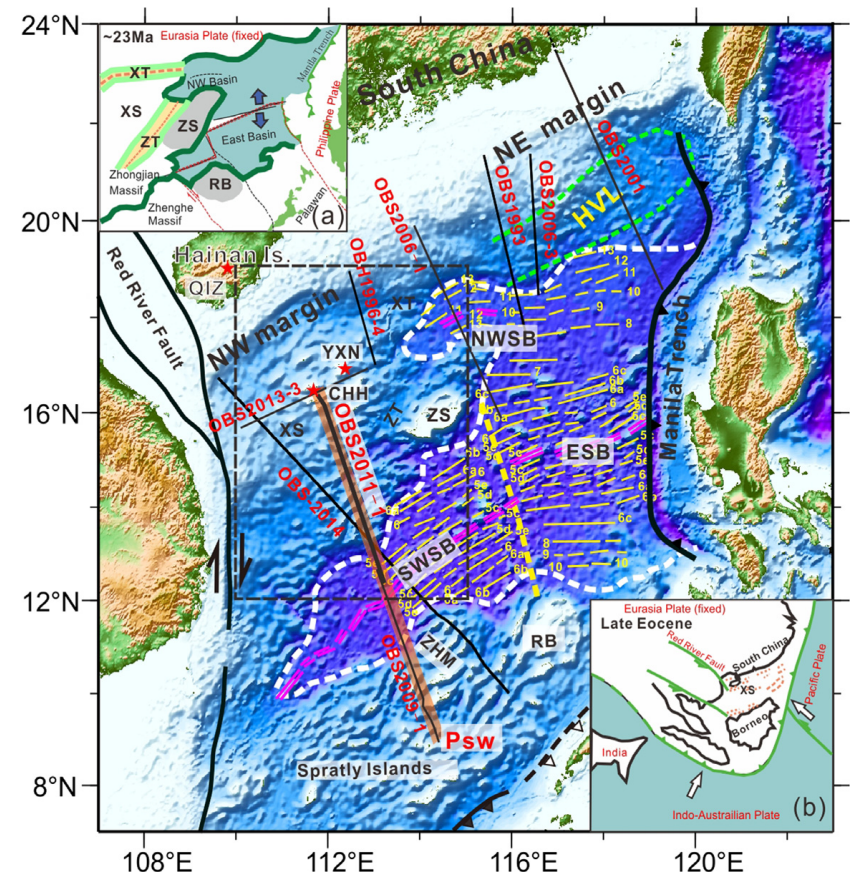

Figure 1. Bathymetric map of the South China Sea. Bathymetry and topography are from ETOPO1 global relief grids. Wide-angle seismic profiles are shown as black lines and labeled, OBS2011-1 (discussed in this article); OBS1993 (Yan et al. 2001); OBS1996-4 (Qiu et al. 2001); OBS2001 (Wang et al. 2006); OBS2006-3 (Wei et al. 2011); OBS2009-1 (Qiu et al. 2011); OBS-2014 (Pichot et al. 2014) and OBS2013-1 (Guo et al. 2016). White broken line is COB after Li et al. (2014a); Yellow solid lines and dashed lines, respectively, are interpreted magnetic anomalies and the Zhongnan Transform Fault from (Briais et al. 1993) and (Li et al. 2011). Heavy black lines with arrows are strike-slip faults, while those with triangles are subduction fronts. Red stars are land seismic stations. Greed dashed line outlines the distribution of the HVL in the northeastern margin. The dashed box denotes the location of Fig. 2. QIZ, Qiongzhong seismic station; CHH, Chenhang portable station; ZHM, Zhenghe massif; ZS, Zhongsha Island; RB, Reed Bank; SWSB, Southwest Sub-basin; ESB, Eastern Sub-basin; NWSB, Northwest Sub-basin. Psw is the long profile (brown thick lines) across the SCS discussed in this paper. Inboxes (a) and (b) are plate kinematic reconstruction sketches simplified from (Sibuet et al. 2016) and (Briais et al. 1993), respectively.

as continental components, lithospheric temperatures and magma supply (Petersen \& Schiffer 2016).

The SCS basin has been formed 30-40 Ma by a rift propagating from east to west (Taylor \& Hayes 1983; Zhou et al. 1995; Sun et al. 2009; Larsen et al. 2018). Three sub-basins called Southwest (SW), Eastern, and Northwest (NW) Sub-basin (Fig. 1) were formed due to the multistaged rifting and migration of the spreading centers in the SCS according to previous geophysical studies (Taylor \& Hayes 1983; Briais et al. 1993). The rifting continued about 30-35 Ma and ended at the onset of seafloor spreading in the Eastern and SW Sub-basin (Franke et al. 2014). High-resolution magnetic data, combined with multibeam bathymetry, revealed that three episodes of the seafloor spreading were involved in the evolution of the SCS, resulting in development of major transform faults from east to west (Zhou et al. 1995; Li et al. 2011; Sibuet et al. 2016). Among these, the Zhongnan Transform Fault zone is the most prominent and separates the Eastern and SW Sub-basin (Fig. 1). Seafloor spreading ended at about 15 Ma probably due to collision of the Dangerous Grounds or North-Palawan Island continental fragment with Borneo and the Philippine Plate at the subduction zone east of the SCS (Barckhausen et al. 2014).

Although it has been studied intensively, many open questions regarding the formation and age of the SCS remain to date. Various models for the formation of the SCS have been proposed in the past. Early work suggested that the collision between India and Eurasia led to the extrusion of the Indochina Peninsula and the formation of the SCS (Tapponnier \& Peltzer 1982). Other models include the proposition that influence of a mantle plume (Hainan Plume) was at the origin of the extension (Flower et al. 1998) and the hypothesis that dragging of the subduction of the Proto-SCS resulted in the extension and formation of the SCS (Taylor \& Hayes 1983; Sun et al. 2009). At present, the model proposing the SCS formed from convergence of the Pacific Plate or the Neotethys Plate towards Eurasia during the Mesozoic-Cenozoic times was recommended (Sun 2016). Plate rollback has been widely accepted as the main cause for the continental rifting not only in the SCS but also in other marginal basins at the edge of Sundaland (Holloway 1982; Sun 2016).

In recent years, several refraction/reflection profiles have been acquired, some of them linking the conjugate margins and therefore allowing drawing conclusions about the extension mechanisms of the SCS. In this paper, we describe the crustal structures in the NW margin of the SCS by using wide-angle ocean bottom seismometer (OBS) data and constructing a complete cross section based on existing profiles (OBS2011-1 and OBS2009-1 in Fig. 1). We compared crustal structures under different tectonic units, trying to discuss the following issues: (1) What is the nature and tectonic history of the crust under the NW margin in response to extension? (2) Which mechanism controls the development of the rift valley and the final continental breakup?

\section{REGIONAL SETTINGS}

The SW Sub-basin has NE-strike symmetric magnetic anomalies. Following a ridge jump at about $25 \mathrm{Ma}$, it began to open and the spreading ceased at anomaly $5 \mathrm{c}(\sim 16 \mathrm{Ma}$, Briais et al. 1993), which was confirmed by recent IODP drilling (Li et al. 2014a). Age of the first oceanic crust in the SW Sub-basin was interpreted mainly according to the magnetic anomaly (Briais et al. 1993; Barckhausen et al. 2014). In the model of Briais et al. (1993), the latest phase of the spreading lasted from $5 \mathrm{e}(\sim 19 \mathrm{Ma})$, but then the age was revised at 6AA1 ( $22 \mathrm{Ma})$ by Barckhausen et al. (2014). Although non-uniform dating and locating was proposed, the initial oceanic crust gets younger from east to west due to the multiphased opening and is located very close $(\sim 30 \mathrm{~km})$ to the continental slope of the NW margin (Fig. 2).

A graben-like and NE trending basin, which is called the Qiongdongnan Basin, developed along the continental shelf (Fig. 2). It has been recognized as the westward continuation of the Xisha Trough, which is proposed to be a failed rift and is underlain by extremely thinned continental crust of less than $10 \mathrm{~km}$ thickness (Fig. 2, Qiu et al. 2001; Huang et al. 2011a). Further offshore, Precambrian basement overlain by a weathered layer of more than $20 \mathrm{~m}$ was sampled in the commercial drillhole Xiyong-1 on Yongxing Island (Fig. 2,Ma et al. 2010). A thin sedimentary layer ( 2.0 km) was modelled beneath the Xisha Islands (Paracel Islands) using receiver functions of portable seismic stations (Huang et al. 2011b).

The Xisha as well as the Zhongsha (Macclesfield) Islands were interpreted as rigid continental blocks once belonging to the South China Block, and they are still seismologically active under tectonic 
stresses and act as on-going or reactivated stretched continent (Ma et al. 2010). Furthermore, Cenozoic volcanism is distributed along the NE-SW and E-W striking fractures in the form of polyphased intrusions and eruptions of basic and ultra-basic magma (Chen et al. 2005). Young volcanic rocks in the Xisha Islands can be compared to those in the late Pleistocene basalt strata of Hainan Island, which were affected by the 'Hainan plume' (Yan et al. 2007). The volcanic rocks are also found within the SCS basins and were dated as post-spreading $(\sim 8-13 \mathrm{Ma})$ seamounts and extrusions along the fault regions and close to the extinct ridges (He et al. 2016; Li et al. 2014a). The post-spreading volcanism is supposed to make identification of the magnetic anomalies more complicatedly (Sibuet et al. 2016).

\section{DATA ANALYSIS AND SEISMIC PHASE IDENTIFICATION}

\subsection{Data acquisition and processing}

The profile OBS2011-1 is located on the NW margin of the SW Sub-basin (Fig. 2) and was acquired together with coincident single channel seismic profiles. Data acquisition was carried out in March-April, 2011. 20 four-component Ocean Bottom Seismometers (OBS) spaced at 10-20 km were deployed along the $\sim 500 \mathrm{~km}$ NNW-SSE-strike profile across the Xisha Islands and the Zhongjian Massif, of which one OBS was lost and another one records no data during the cruise (Fig. 2). Two portable seismometers were installed at the same site on Chenhang Island to record the air-gun signals in order to extend the profile. Four air-guns with a total volume of $6000 \mathrm{in}^{3}$ ( 96 1) were deployed at $30 \mathrm{~m}$ behind R/V Shiyan II, $10 \mathrm{~m}$ below the sea level and shot every $110 \mathrm{~s}$ during the cruise, leading to a $\sim 300 \mathrm{~m}$ shot spacing. OBS2011-1 coincides with OBS2009-3, a wide-angle seismic profile acquired during April-June 2009. Due to technical problems, only four of the total 20 OBSs were recovered during that cruise. We included data from these four Chinese-made OBSs in our modelling (Fig. 2).

Huang et al. (2011a) have processed records of 5 OBSs and the portable station $\mathrm{CHH}$ along this profile and an adjoining profile to the north. The main purpose was to constrain the crustal structure beneath the Xisha Islands, and thus the abyssal area was ignored. Lü et al. (2017) have studied the continental crust by preliminary tomography mapping using only the marine receivers in OBS20111 . The models they obtained revealed a rough crustal structure since secondary reflection arrivals from sedimentary and mid-bottomcrustal boundary were not included for the modelling. Furthermore, a 1000-km-long profile intersecting the OBS2011-1 was acquired along the conjugate margins of the SW Sub-basin (OBS-2014 in Fig. 1), nearly perpendicular to the spreading axis (Pichot et al. 2014), which thus allows an along-strike comparison of the crustal structures. We processed all available seismic data of OBS2011-1 to improve the ray coverage and extended the profile using the land stations. We also calibrate and recover one station of the Germany instruments, OBS03, which has abnormal data and was ignored before (Wang et al. 2016). A total of 23 stations, including 18 OBSs from OBS2011-1, one portable seismograph station on Chenhang Island and four OBSs from OBS2009-3 (Fig. 2), were involved in the traveltime forward and inversion modelling. The single channel seismic data were also included to constrain shallow structures along OBS2011-1, and it shows very similar features with the reflection seismic profile in Lü et al. (2017).

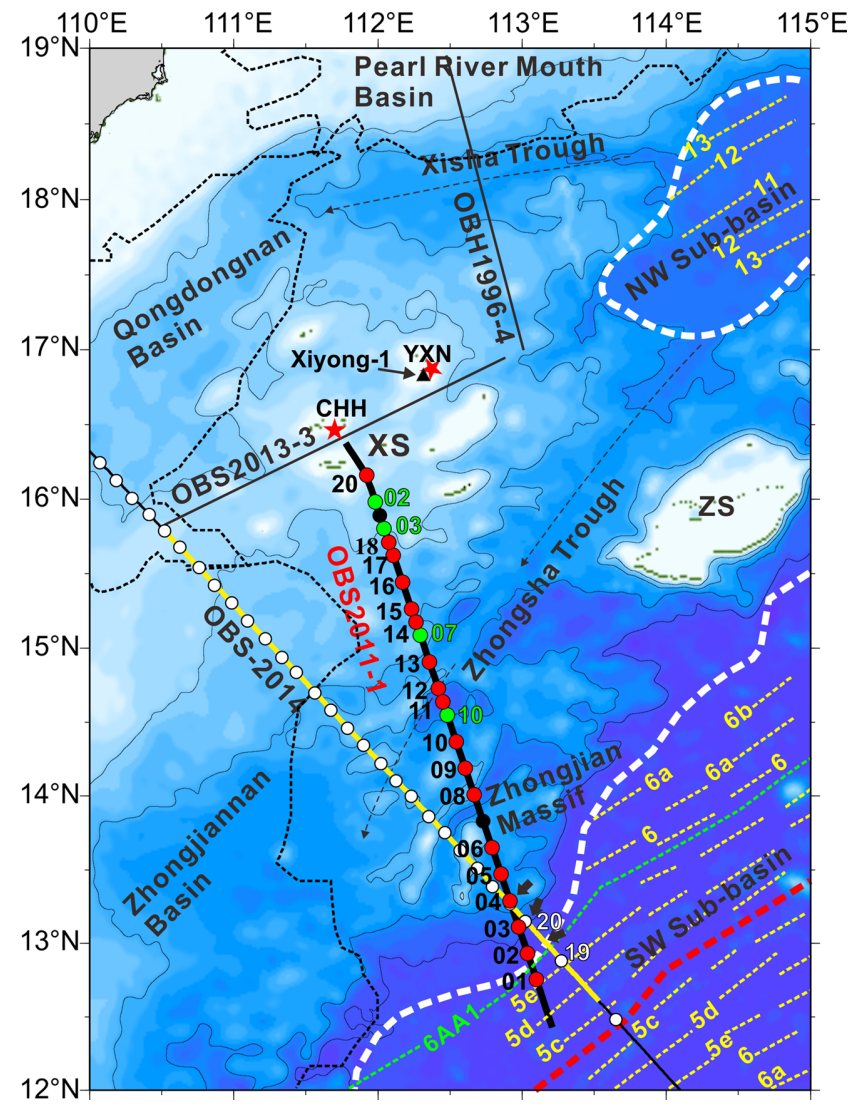

Figure 2. Location of the wide-angle seismic profile in the Xisha Islands. Ocean bottom seismometers (OBS) are marked by circles and labeled by the station numbers. Green circles mark the OBSs from OBS2009-3, while red circles mark those from OBS2011-1 used in this paper. Black circles mark the lost or invalid OBSs from OBS2011-1. Red stars mark the portable stations on Chenhang $(\mathrm{CHH})$ and Yongxing $(\mathrm{YXN})$ islands. Thin broken lines with arrows indicate distribution of troughs. Dash outlines represent the sedimentary basins taken from Larsen et al. (2018). Thin yellow broken lines represent the interpreted magnetic anomalies from (Briais et al. 1993), while the green broken line is the interpreted magnetic anomaly of 6AA1 from (Barckhausen et al. 2014). Red broken line is the abandoned spreading ridge of the SW Sub-basin. Black solid arrows show the comparative points between crustal structures of OBS2011-1 and OBS-2014 (Fig. 11). White circles denote the OBSs in OBS-2014, beneath which the yellow line denotes the model segment for comparison in Fig. 10(c). OBS19 and OBS20 in OBS-2014 are labeled by the station numbers. Black triangle is the Xiyong1 drillhole. ZS, Zhongsha Islands; XS, Xisha Islands; $\mathrm{CHH}$, Chenhang portable station; YXN, Yongxing portable station.

OBS data were corrected assuming a linear drift of the internal clock. The position of the instrument on the seafloor was constrained by fitting the direct water-wave phases using the least-square method (West et al. 2001). The signal-to-noise ratio was enhanced by application of a bandpass Butterworth filter with corner frequencies of 3-15 Hz and whitening deconvolution. Far-offset arrivals originating from deep layers were further enhanced by application of an automatic gain. The single channel seismic data were processed using the software package Seismic Unix (Stockwell 1999), applying the basic steps of sorting, filtering and automatic gain.

\subsection{Seismic phase identification}

All OBS gave data of high quality and arrivals from the lower crust and upper mantle were identified along most record sections. Fig. 

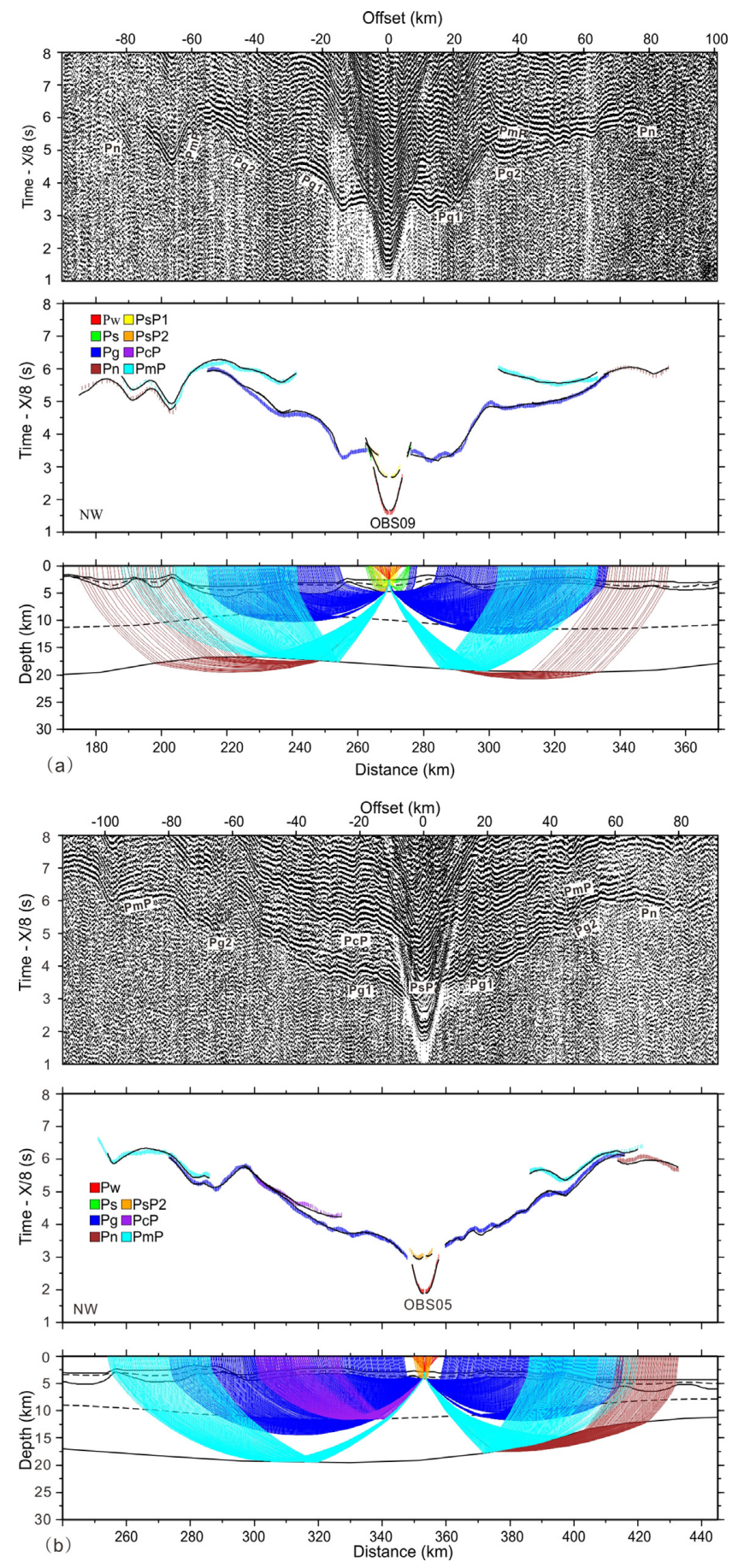

Figure 3. Two examples of seismic record sections and ray paths. (a) Seismic record of OBS09 on the southern flank of Zhongsha Trough (top), the traveltime fits (middle) between calculated (solid black lines) and observed (coloured lines), and the corresponding ray paths in the forward model (bottom panel). In the middle figure, Pg includes Pg1 and Pg2. (b) Seismic record of OBS05 in the middle of Zhongjian Massif. Seismic records are plotted with a reduced velocity of $6.0 \mathrm{~km} \mathrm{~s}^{-1}$ and the identified phases are labelled.

3 shows two examples of seismic records and phase identification, displaying clear refracted arrivals from sediments (Ps) where sedimentary layers are thick (Fig. 3a). The most prominent phases are refracted arrivals from the crust $(\mathrm{Pg} 1, \mathrm{Pg} 2)$, which can be identified to $100 \mathrm{~km}$ away for most of record sections in the shallow water.
Arrivals from the upper mantle (Pn) are also identified from both stations. Reflected arrivals from velocity discontinuities are not always distinct because they arrive as secondary phases and often are obscured by reverberations. Calculated travel times based on an earlier velocity model can help to confirm these later arrivals. It is possible to pick the Moho reflection (PmP), the reflections on a mid-crustal boundary (PcP) and of the sedimentary interfaces ( $\mathrm{PsP} 1$ and PsP2) along most record sections for the seismic modelling. PcP phases present a good constraint on the mid-crustal interface beneath the station (Fig. 3b).

A total of 16213 arrivals including 10428 from turning waves (excluding the direct water wave) and 5158 from reflected waves were picked. Picking uncertainties were assigned to each phase based on the signal-to-noise ratio using the method of Zelt (1999). Generally, refracted phases at near offset were assigned low picking errors ranging in 30-60 ms, whereas phases from far offsets or disturbed by reverberation were assigned high values in $60-80 \mathrm{~ms}$.

\section{TRAVELTIME MODELLING}

\subsection{Forward modelling}

On the basis of the picked reflection phases (Ps1, Ps2, PcP and PmP), the initial forward model was comprised of five layers including two sedimentary layers, upper crust, lower crust and upper mantle. Geometries and velocities of the sedimentary layers were constrained mainly by modelling the refracted and reflected phases and the reflectors from the single-channel seismic profile (Fig. 4).

The picked traveltimes were modelled using the top-down method (Zelt \& Smith 1992) starting with the shallow layers and ending with the deepest ones. Modifications were applied to the initial model in order to decrease the misfit between the picked and calculated arrivals consistent with geological information and structures identified in the reflection seismic section. During the forward modelling, velocities and depth of model nodes were inverted using software of Zelt et al. (1992) to further decrease the RMS errors (root-meansquare value of the misfit) and values of $\chi^{2}$ (chi-square value of the misfit). To avoid overfitting some minor variations of the basement, only partial modifications of the model parameters during the inversion were accepted for improving the forward model. The RMS and $\chi^{2}$ measures of the traveltime misfit for each phase (Table 1) give information about the quality of the final forward model (Fig. 5). The corresponding values of RMS error and $\chi^{2}$, respectively are 0.079 and 1.591 using 97.2 percent of the picked traveltimes.

\subsection{Tomographic traveltime inversion}

Forward modelling of wide-angle seismic data can be userdependent but can also include a priori information on the velocity structure, including the layer geometry and velocity gradients, therefore additionally constraining the velocity structure. Tomographic approaches allow constructing a user-independent velocity model, but do not allow including additional information, such as coincident reflection seismic record sections. A combination of both approaches as presented in this paper was used to include all available information into the modelling with the tomographic inversion, showing that no over interpretation of the data was done. It is therefore a time-consuming but ideal approach to wide-angle seismic data modelling. 

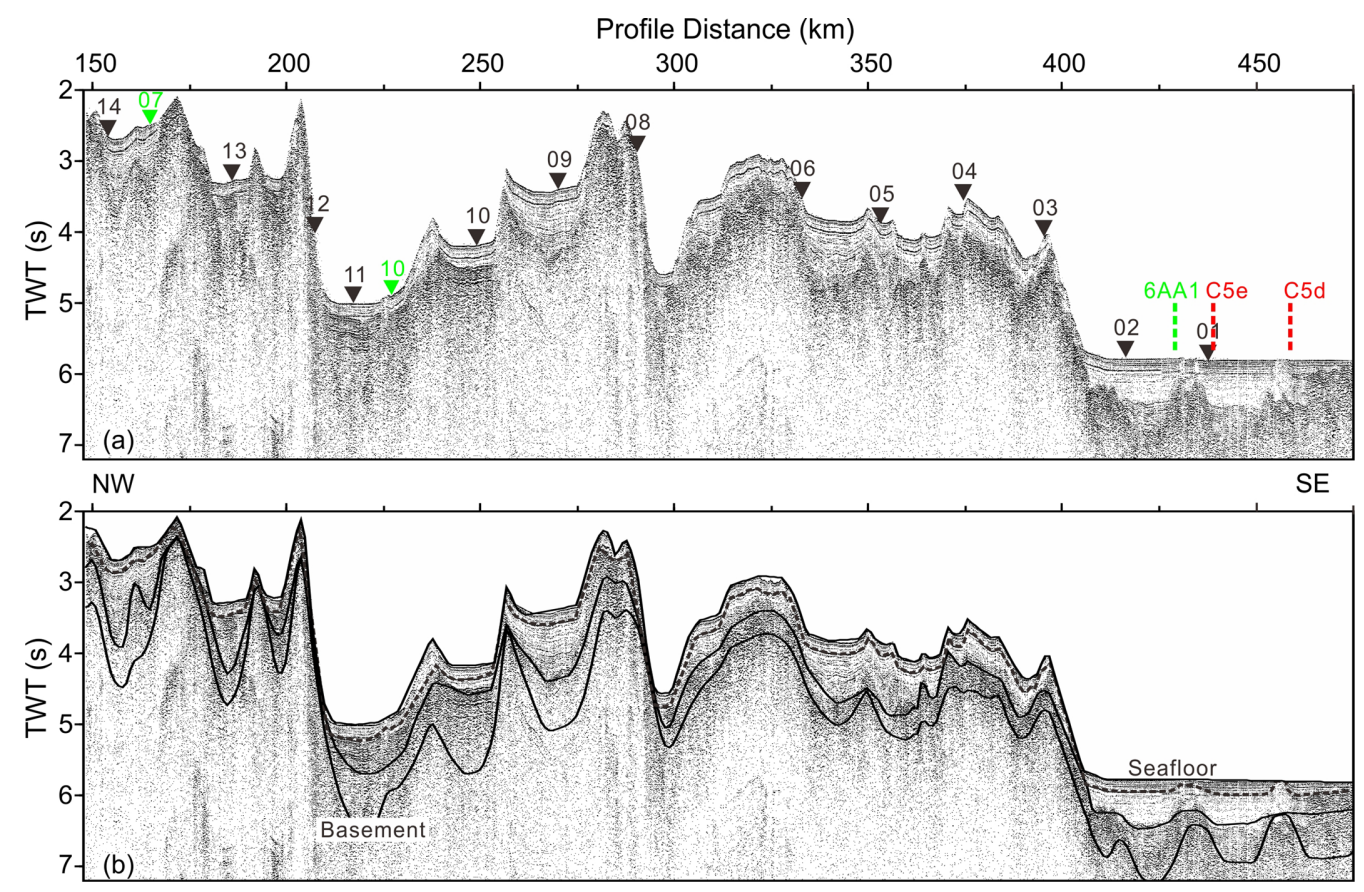

Figure 4. (a) Raw single-channel seismic data; and (b) the data with overlain sea bottom, sedimentary discontinuity and the basement (heavy lines) from forwarding model. Green triangles mark the OBSs from OBS2009-3, while red ones mark those from OBS2011-1. Thin broken line is possible sedimentary discontinuities picked by hand but not incorporated into the model due to low resolution and high uncertainty.

Table 1. Number of picks, RMS and $\chi^{2}$ for all phases used in forward modelling.

\begin{tabular}{lccc}
\hline Phase & Name & Number of picks & RMS(s) \\
\hline Water & Pw & 621 & 0.043 \\
Sediment refraction & Ps & 172 & 0.058 \\
Refraction in the crust & Pg & 9337 & 0.744 \\
Refraction in the upper mantle & Pn & 624 & 1.351 \\
Reflection at the inner-sedimentary boundary & PsP1 & 264 & 1.802 \\
Reflection at the inner-sedimentary boundary & PsP2 & 2239 & 0.073 \\
Reflection at the mid-crustal boundary & PcP & 369 & 0.048 \\
Reflection at the Moho & PmP & 4139 & 0.061 \\
\hline
\end{tabular}

We thus constructed a tomographic model using the Tomo2D software package (Korenaga et al. 2000), which jointly inverts refraction and reflection traveltimes. The inversion results can be compared with the forward model to ensure the main velocity structures are recreated independently. We used $\mathrm{Pg}$ and $\mathrm{PcP}$ first to invert velocity of the upper crust as well as depth of the mid-crustal boundary, and then the PmP were included for the complete crust based on the previous inversions. The sedimentary structures and the basement geometry of the forward model were introduced into the initial models, since they have been well controlled by the shallow phases. As shown in Fig. 6(b), the inverted mid-crustal boundaries are well matched by the forward ones, and the Moho depths are also strikingly consistent. Compared to the forward model, more details have been revealed mainly in the upper crust beneath the Zhongjian Massif and in the lower crust beneath the Zhongsha Trough.

The Tomo2D model was parameterized with grid cells and a node spacing of $0.5 \mathrm{~km} \times 0.25 \mathrm{~km}$, and the Moho was defined with a uniform $1 \mathrm{~km}$ spacing. The final model used horizontal correlation lengths of $1 \mathrm{~km}$ and $8 \mathrm{~km}$ at the top and bottom, respectively. Accordingly, the vertical correlation length increased from 0.2 to $4 \mathrm{~km}$. We applied a correlation length of $2 \mathrm{~km}$ for the Moho reflectors in the distance range of $0-150 \mathrm{~km}$ and $4 \mathrm{~km}$ along the other part, according to the Moho duration indicated by the forward model. The mid-crustal boundary was given a $1 \mathrm{~km}$ correlation length, since only a few PcP phases were identified. The smoothing weighting factors for the velocity and depth were 200 and 20 , respectively.

\subsection{Uncertainty of the tomographic model}

Using 100 random initial crustal models (Fig. 7a) and inversions; we derived an average velocity model from the best results, which has an overall RMS misfit of $63.5 \mathrm{~ms}\left(\chi^{2}=1.2\right)$. Monte Carlo tests were applied to assess the resolution and uncertainty of the final Tomo2D model (Korenaga et al. 2000). The 100 randomized 1-D velocity models have been constructed by flat mid-crustal boundaries in a depth range of 4-9 km and the Moho of 13-23 km, hanging beneath the sediments. Velocity at the base of the models was set to $7.5 \mathrm{~km} \mathrm{~s}^{-1}$ since upper mantle structures are not inverted. The standard deviation of the average velocity model of all the Monte Carlo inversions for each 1-D profile is shown in Fig. 7(b). The velocities are well constrained with uncertainties smaller than $0.1 \mathrm{~km} \mathrm{~s}^{-1}$ in most part of the model (Fig. 7b), except in the edge area and the base of the model $\left(>0.2 \mathrm{~km} \mathrm{~s}^{-1}\right)$ where the ray density was low [seeing derivative weight sum (DWS) in Fig. 7c]. The deviations of the mid-crustal boundary and the Moho depth are mostly better 


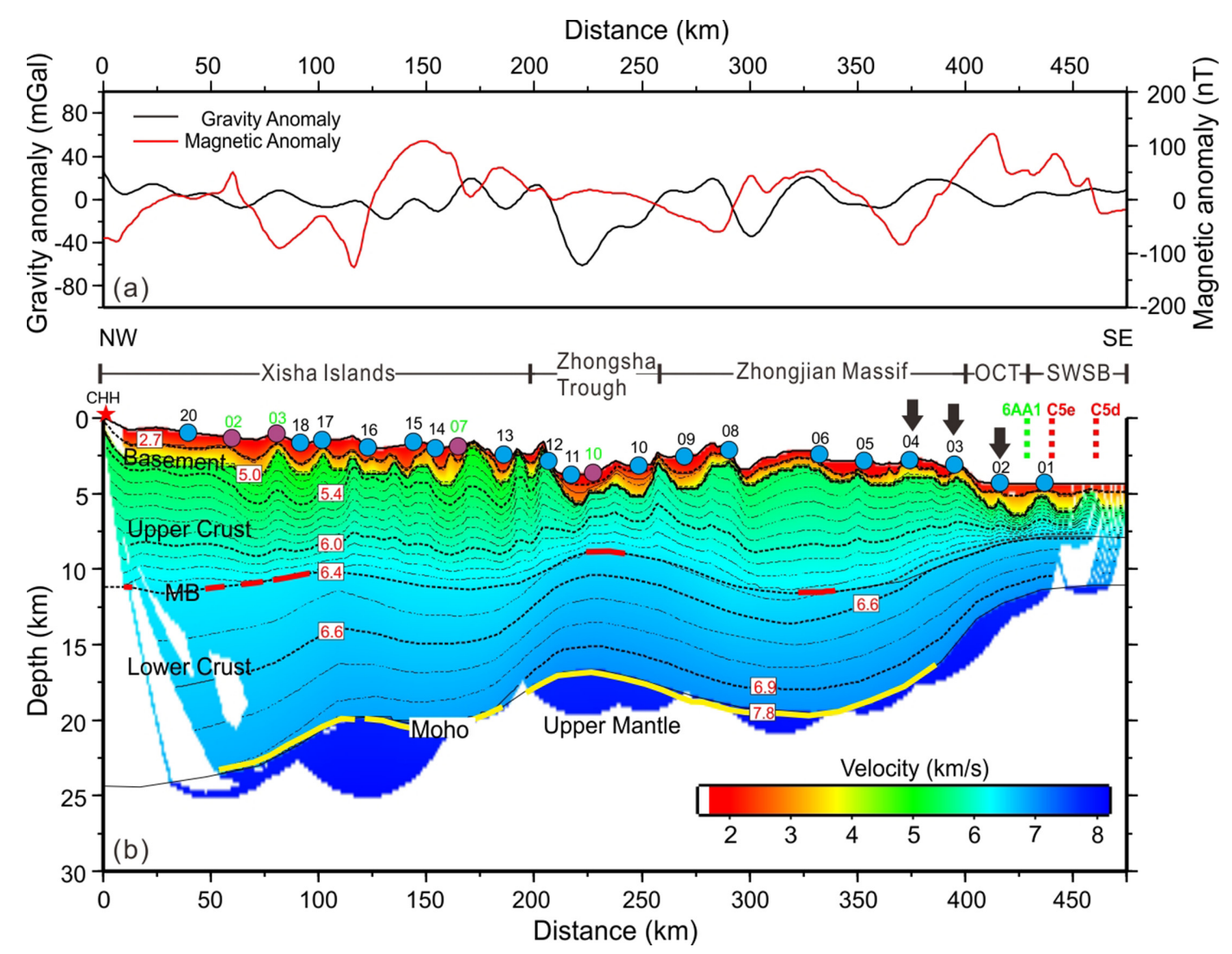

Figure 5. Final forward velocity model of OBS2011-1. (a) Gravity and magnetic anomaly along the profile. (b) Forward model in this paper. CHH: the Chenhang portable seismic station. Isovelocity contours in the crust are represented every $0.1 \mathrm{~km} \mathrm{~s}^{-1}$. OBS locations are represented by blue and purple circles. Red lines denote the mid-crustal boundaries where PcP phases are traced. Yellow lines denote the Moho where PmP phases are traced. Black arrows indicate the comparative points of the velocity-depth profiles in Fig. 11. OCT, Ocean-Continent Transition zone; SWSB, Southwest Sub-basin; MB, mid-crustal boundary.

than $\sim 1.5$ and $\sim 2 \mathrm{~km}$, respectively, across the central regions and where reflection phases were identified.

\subsection{Gravity modelling}

Using a velocity-to-density conversion based on empirical laws (Koranaga et al. 2001), a theoretical gravity anomaly was calculated and compared to satellite gravity data (Fig. 6a). This allows confirming the velocity model and extending it to regions unconstrained by the seismic data. No gravity modelling was undertaken in the earlier studies of part of this data set. The observed gravity is extracted from compilation of Sandwell \& Smith (2009) and has a high resolution in most areas except for some narrow seamounts where the satellite gravity may underestimate shipboard measurements by up to $20 \mathrm{mGal}$ (Sandwell \& Smith 2009). Finally, we obtain a good fit of the observed gravity with a misfit of $15.7 \mathrm{mGal}$ for the entire forward model, which indicates a well resolved crustal structure in the model. The mesh range of the Tomo2D model for gravity calculation is limited within 5-400 km, since this region has been well constrained, and the misfit is $11.3 \mathrm{mGal}$. We also obtained the misfit of $13.5 \mathrm{mGal}$ for the forward model in this range. Improvement of the misfits between the forward and Tomo2D models is mainly due to revisions of the velocity structures in the model distance of $100-300 \mathrm{~km}$.

\section{RESULTS}

\subsection{Velocity model}

In the final forward model (Fig. 5b), a $\sim 2.5$-km-thick Cenozoic sedimentary layer can be observed, in which velocities vary laterally between 1.8 and $2.3 \mathrm{~km} \mathrm{~s}^{-1}$ at the top and $3.0-4.5 \mathrm{~km} \mathrm{~s}^{-1}$ in the bottom. Across the Zhongsha Trough (200-230 km model distance), the seafloor and the sedimentary basement deepen to $\sim 3.5$ and $\sim 6 \mathrm{~km}$ depth, respectively, forming an $11^{\circ}$ slope. The sedimentary thickness increases in the centre of the trough where faulted blocks from rifting create a steep relief, and $P$-wave velocities at the bottom of the sedimentary layer decrease to as low as $3 \mathrm{~km} \mathrm{~s}^{-1}$. By contrast, a relatively smooth basement with only a few grabens and highs can be observed between distances of 0-70 and 300-400 km (Fig. 5b). In the deep basin, sediment thickness varies thinning above seamounts (Fig. 5b). However, on a larger scale the total sedimentary cover varies less and progressively thickens toward the base of the margin.

Beneath the sedimentary layer, the top of the crust has a velocity of 5.0-5.6 $\mathrm{km} \mathrm{s}^{-1}$ (Figs $5 \mathrm{~b}$ and $6 \mathrm{~b}$ ). Along the Zhongsha Trough (distance at 200-300 km), velocities of the top crust range in 5.4 $5.5 \mathrm{~km} \mathrm{~s}^{-1}$, up to $0.5 \mathrm{~km} \mathrm{~s}^{-1}$ higher than the flanks on both sides in the forward and Tomo2D model (Fig. 6c). The relatively low velocities of the top crust in the Xisha Islands suggest that strong faulting and weathering reduced the velocities of the blocks during rifting, which agrees well with the logging results (Ma et al. 2010). Velocities across the boundary of the upper and lower crust generally remain unchanged except in the Zhongsha Trough where the velocities 

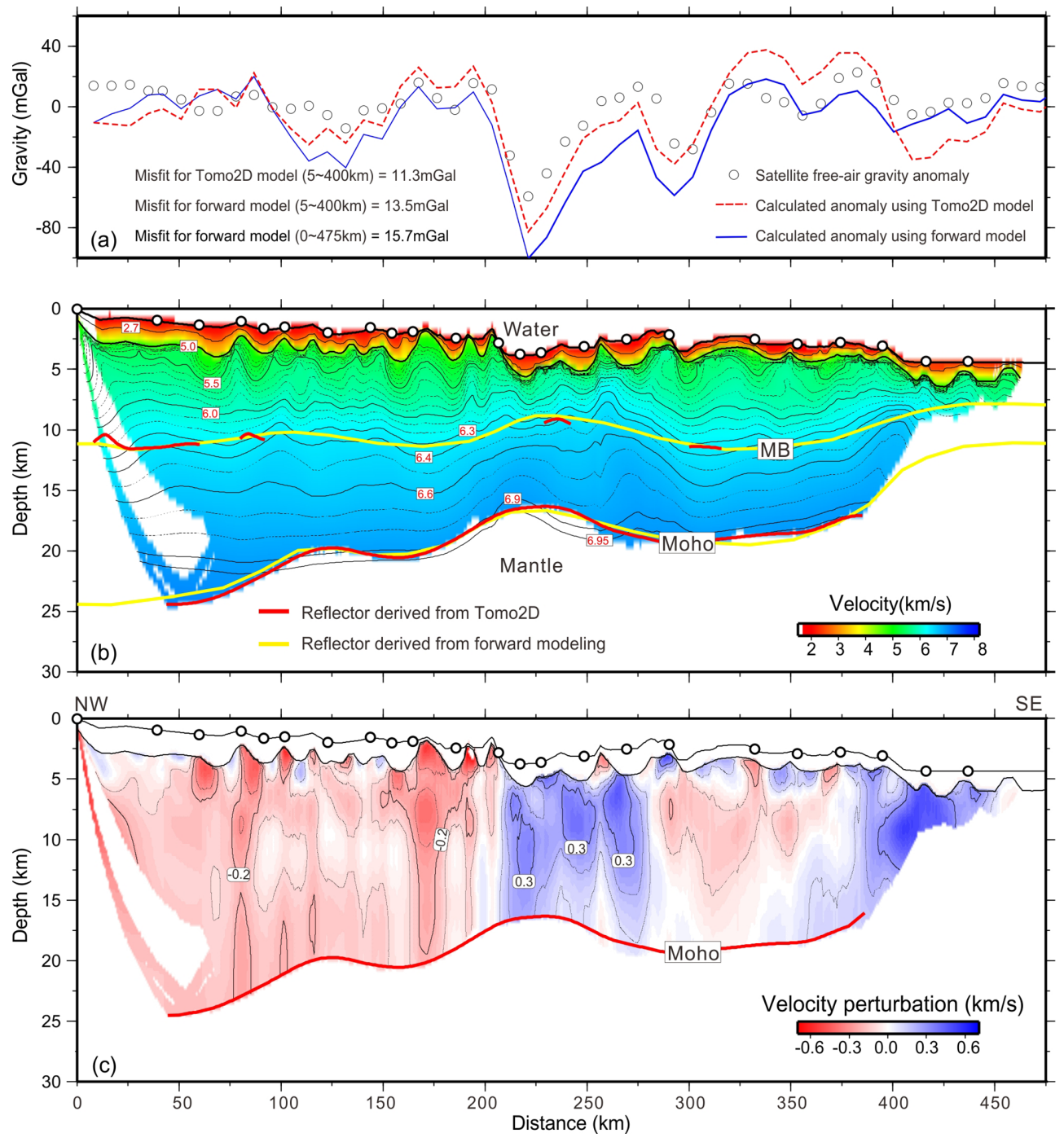

Figure 6. Velocity model from tomographic inversion and the gravity modelling. (a) The gravity modelling; (b) the velocity model; (c) velocity perturbation. $\mathrm{MB}$, mid-crustal boundary.

increase by $\sim 0.1 \mathrm{~km} \mathrm{~s}^{-1}$ in the forward model. At the bottom of the lower crust, velocities vary between 6.8 and $7.0 \mathrm{~km} \mathrm{~s}^{-1}$ and exceed $6.9 \mathrm{~km} \mathrm{~s}^{-1}$ generally at distances greater than $190 \mathrm{~km}$ in the models. Velocities of the upper mantle vary between 7.8 and $8.1 \mathrm{~km} \mathrm{~s}^{-1}$ in the forward model.

The Moho is located at a depth between 23 and $25 \mathrm{~km}$ below the Xisha Islands and rises towards the abyssal region. Across the Zhongsha Trough, the Moho rises stepwise from $\sim 20 \mathrm{~km}$ beneath the flanks to $\sim 17 \mathrm{~km}$ in the centre of the trough, accompanied by an uplifted mid-crustal interface and a thickened sedimentary layer (Figs $5 \mathrm{~b}$ and $6 \mathrm{~b}$ ), which contributed to the negative gravity anomaly (Fig. 6a). In the deep basin, the Moho is constant at a depth of $11-12 \mathrm{~km}$ while the basement is located at $\sim 6 \mathrm{~km}$ depth (Fig. $5 \mathrm{~b}$ ).

\subsection{Comparison with the conjugate margin profile}

A 950-km-long profile (Psw in Fig. 1) spanning the complete SWSB can be constructed referring to the velocity models of OBS2011-1 and OBS2009-1 (Qiu et al. 2011; Yu et al. 2017). This helps us to compare the crustal structures of the conjugate margins, spanning from the Xisha Islands to the Spratly Islands, crossing the Zhongsha Trough, the Zhongjian Massif and the deep basin (Fig. 8c). Stretching factor $(\beta)$ and thickness ratio between upper and lower crust $\left(T_{u c} / T_{l c}\right)$ are also calculated over the continent parts (Figs $8 \mathrm{a}$ and b) for comparison and discussion afterward.

The Psw-profile shows that the SE margin is covered by a sedimentary layer with thickness of $1-3 \mathrm{~km}$ and velocity of $2.5-$ $4.5 \mathrm{~km} \mathrm{~s}^{-1}$ spreading over the deep basin, which is comparable to the results from the NW margin. The thickest sedimentary layer is located in the center of the deep basin (at distance $\sim 510 \mathrm{~km}$ in Psw) bordered by basement highs on both sides. The crystalline basement also shows variable seismic velocities in a range of $5.0-5.4 \mathrm{~km} \mathrm{~s}^{-1}$ due to faulting and erosion. Moho depth reaches $24 \mathrm{~km}$ beneath the Zhenghe Massif, which is $\sim 4 \mathrm{~km}$ deeper than the Zhongjian Massif. The Moho rises progressively to $11 \mathrm{~km}$ in the deep basin over a distance of $\sim 80 \mathrm{~km}$ and shows few variation, thus forming a variable crustal thickness in a range of 4-6 km mainly due to the basement undulation. Overall, comparison between the NW and SE margin indicates similar range of velocities and velocity gradients, which supports the common origin of these two margins. 

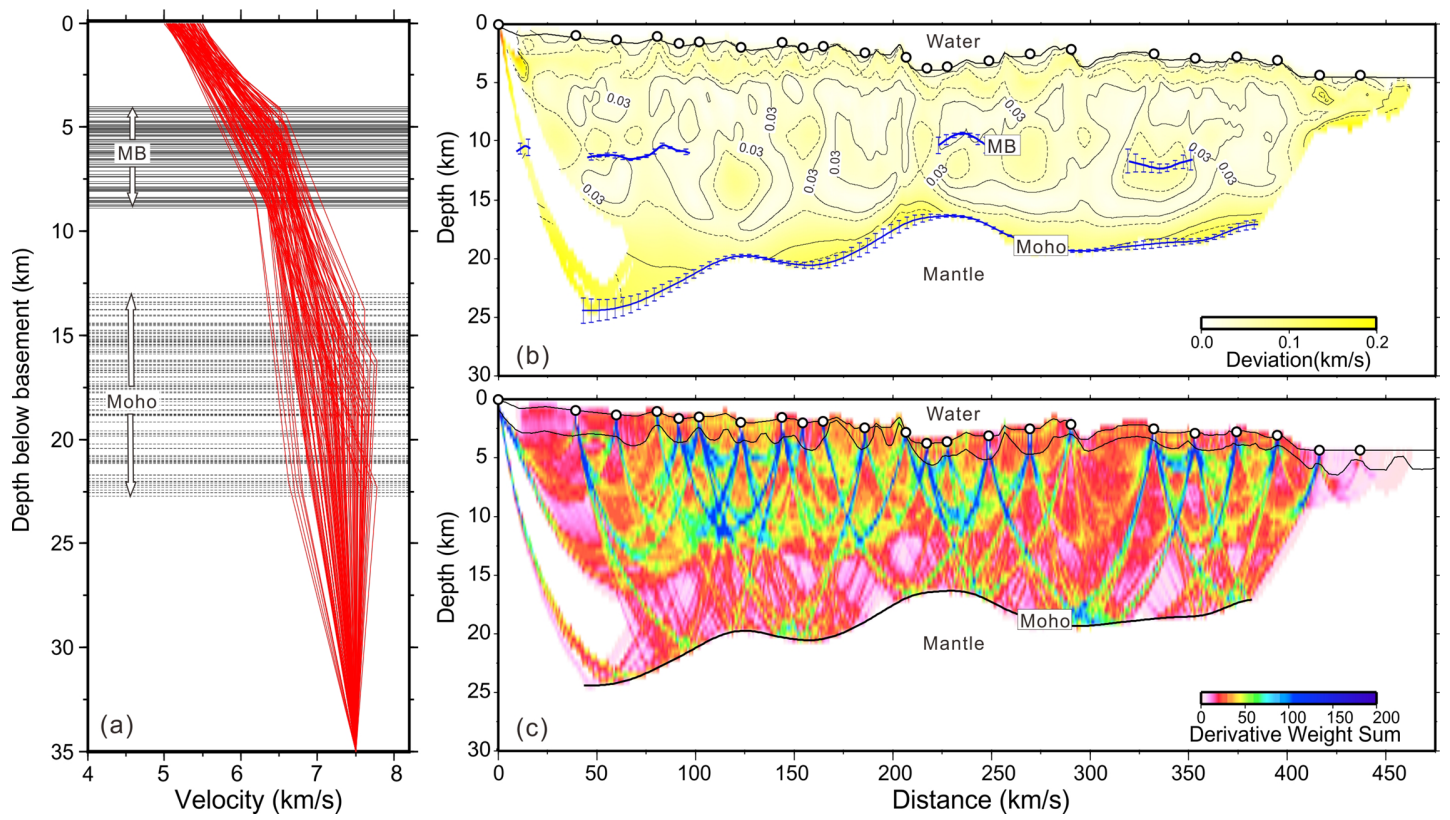

Figure 7. Uncertainty of the tomographic model and the Monte Carlo test. (a) the 100 starting 1-D models for Monte Carlo test; (b) uncertainty of the velocity model and the depths of Moho; (c) DWS of the model. MB, mid-crustal boundary.
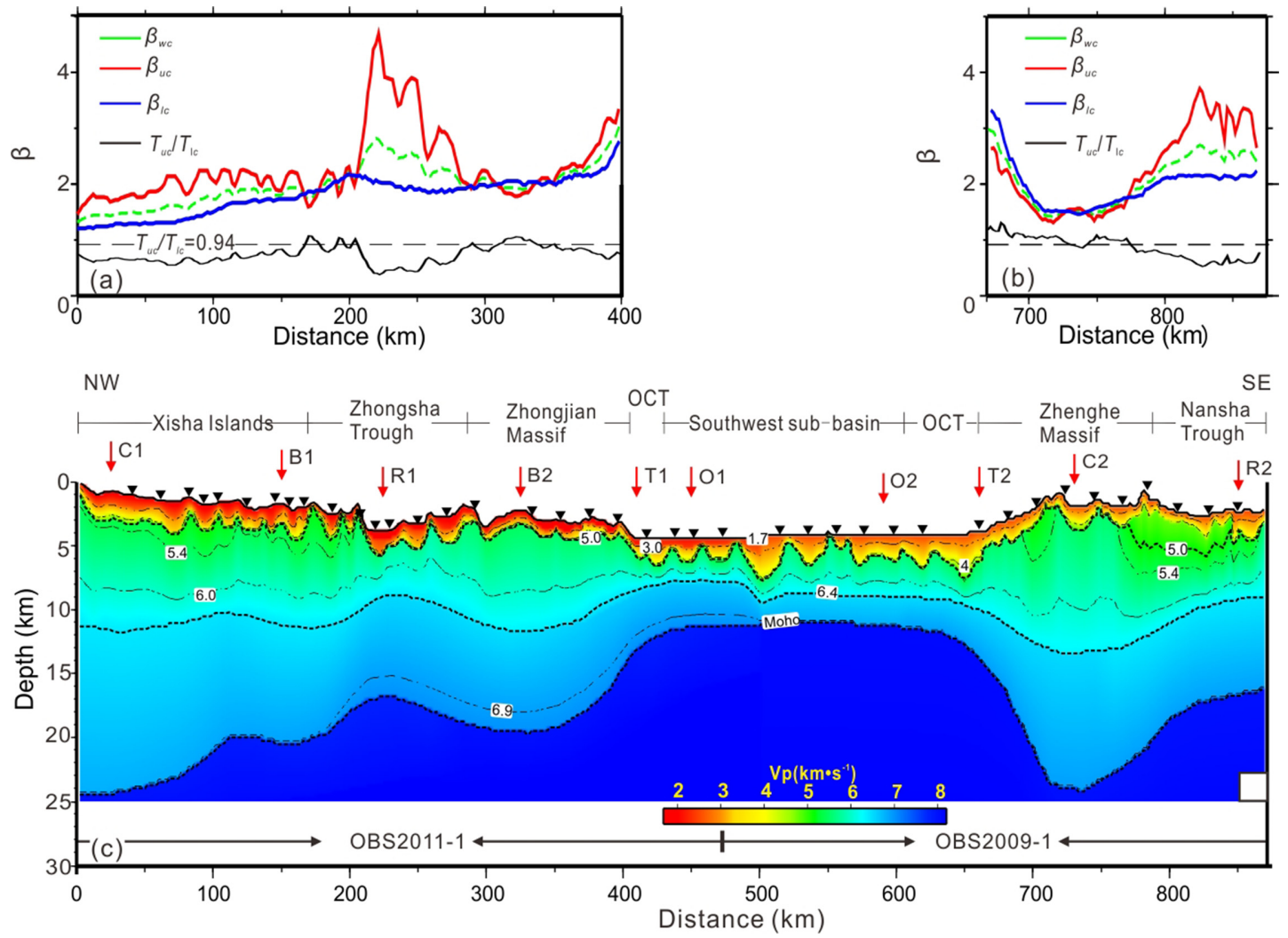

Figure 8. Crustal structures of the Psw-profile. (a) Crustal stretching factor $(\beta)$ and $T_{u c} / T_{l c}$ value in northwest of Psw, in which $T_{u c}$ is the upper crustal thickness; $T_{l c}$ is the lower crustal thickness. The horizontal broken line indicates the initial value of $T_{u c} / T_{l c}(15 \mathrm{~km} / 16 \mathrm{~km} \sim=0.94)$. (b) Crustal stretching factor $(\beta)$ and $T_{u c} / T_{l c}$ value in southwest of Psw. (c) Velocity model of profile Psw based on our seismic refraction profile and OBS2009-1 presented by (Qiu et al. 2011). The red arrows indicate the 1-D velocity-depth models presented in Fig. 9. The main geological provinces are annotated. The positions of each OBS are represented by black triangles. OCT, Ocean-Continent Transition zone 


\subsection{Nature of the crust}

Several velocity-depth profiles (Fig. 9) were extracted from below the top of the basement of Psw-profile (Fig. 8c). These profiles were compared to existing compilations of the velocity-depth profiles for typical thinned continental crust (Christensen \& Mooney 1995) and Atlantic-type oceanic crust (White et al. 1992), in order to provide information on the nature of the crust. Four types of crust can be distinguished corresponding to different tectonic units.

In the deep basin where magnetic anomalies were interpreted (model distances between 425 and $626 \mathrm{~km}$ ), 1-D velocity-depth profiles (O1 and $\mathrm{O} 2$ in Fig. 9) show a two-layer structure with a high velocity gradient in the upper layer $(\sim 0.7 / \mathrm{s})$ and a lower gradient in the lower layer $(\sim 0.2 / \mathrm{s})$, typical for the basaltic layer 2 and gabbroic layer 3 in the oceanic crust. The thickness varies between $\sim 1.8$ and $2.3 \mathrm{~km}$ for the upper and between $\sim 2.3$ and $3.2 \mathrm{~km}$ for the lower layer. The total crustal thickness is $\sim 5 \mathrm{~km}$, which is a about $2 \mathrm{~km}$ less than the thickness of the typical Atlantic oceanic crust ( $\sim 7.2 \mathrm{~km}$, White et al. 1992) but close to the values found in backarc basins (Gailler et al. 2009) and other magmapoor margins with slow spreading rates (Chian et al. 1995). Crustal thickness and seismic velocity of the layer 3 is $\sim 1 \mathrm{~km}$ and $0.1 \mathrm{~km} \mathrm{~s}^{-1}$ higher in the NW part than the SW, generally.

At 410 and $680 \mathrm{~km}$ on both sides of the deep basin, the profiles (T1 and T2) exhibit slightly lower velocities than in the deep basin and faster than in continental crust. These velocities between typical oceanic and continental values are typically found in OCT type of the crust (Dean et al. 2000; Funck et al. 2004). The total thickness of the crust increases to $7.5 \mathrm{~km}$ and reaches the value of the continental crust $(\sim 20 \mathrm{~km})$ in a very narrow transition zone $(\sim 20-40 \mathrm{~km})$.

The profiles $(\mathrm{C} 1, \mathrm{C} 2, \mathrm{~B} 1$ and $\mathrm{B} 2)$ correspond to the continental margins of the deep basin. In these domains, velocities and velocity gradients of the crust are consistent with typical or thinned continental crust (Christensen \& Mooney 1995). Crustal thickness in the Xisha Islands (C1) is similar to that of the Zhenghe Massif (C2) in the SE margin at about 20-21 km. In the south of the Xisha Islands (B1) and the Zhongjian Massif (B2), thicknesses of the crust are $\sim 15$ and $\sim 17 \mathrm{~km}$, respectively, resembling stretched continental crust; thereby supporting the hypothesis that they are both separated rigid blocks. Between the rigid blocks, the Zhongsha Trough and the Nansha Trough are both characterized by an uplifted Moho and a depressed basement. In these domains, the 1-D profiles (R1 and R2) depict the velocity distribution between the blocks and the OCT, shown as aborted rift valleys (Qiu et al. 2001).

\section{DISCUSSION}

On the basis of the detailed crustal structures imaged along the Pswprofile, structural relationships between different tectonic units on the conjugate margins of the SW Sub-basin can be discussed more specifically.

\subsection{Existing seismic studies across the NW margin}

The profile OBS-2014 is located close to the Psw-profile, and they intersect at the south of the Zhongjian Massif (Fig. 1). A tomographic model was obtained only using the first refracted arrivals and the reflections from Moho without introducing extra interfaces in sediments and crust (Fig. 10c). Main structures regarding the crustal variations between massifs, rifts and the deep basin basically coincide with the Psw-profile (Fig. 10). Especially, the Moho depth under major tectonic units is highly consistent with our results
(Fig. 11). Owing to the reflected arrivals recorded in the OBSs, our model shows more sedimentary structures and a well-constrained mid-crustal boundary (MB in Figs $5 \mathrm{~b}$ and $6 \mathrm{~b}$ ). The thin highvelocity layers (HVL, $2-3 \mathrm{~km}$ thick) beneath the continental blocks in OBS-2014 were not observed in our model. However, existence of the HVL is still uncertain due to inadequate constraints from the refracted arrivals in the lower crust and lack of the reflections from top of the HVL. By far, studies on the crustal structures of the NW margin suggest an less prominent or absent HVL (Qiu et al. 2001; Wu et al. 2011; Ding et al. 2012; Pichot et al. 2014; Yu et al. 2017; this work), as compared with the NE margin where a HVL with velocity of 7.3-7.5 $\mathrm{km} \mathrm{s}^{-1}$ and thickness of several kilometres was detected along the OCT (Yan et al. 2001; Wang et al. 2006; Wei et al. 2011). Distribution of the HVL may imply that the northern margin experienced different magmatic history laterally (Pichot et al. 2014). Rather than magmatic underplating for the HVLs in the NE margin (Wei et al. 2011), the lower crust beneath the Zhongsha Trough with an increasing velocity by up to $\sim 0.3 \mathrm{~km} \mathrm{~s}^{-1}$ (Fig. $6 \mathrm{c}$ ) possibly due to magmatic addition during evolution of the rifts (Thybo \& Nielsen 2009). The reflective top of the lower crust in the Zhongsha Trough might represent the front of the intruded material (Chian et al. 1995), which created a velocity contrast across the boundary (Figs $5 \mathrm{~b}$ and $6 \mathrm{~b}$ ).

Lü et al. (2017) presented a different velocity model along OBS2011-1 by using less data and a different strategy. The model shows much shallower mid-crustal boundary at around $\sim 6 \mathrm{~km}$ and the Moho no deeper than $\sim 17 \mathrm{~km}$, in contrary to the models of OBS2014 and of this work (Figs 10and 11). However, the teleseismic study beneath the Chenhang Island revealed a thinned crust (thickness of $\sim 26 \mathrm{~km}$ ) with a mid-crustal boundary at $\sim 12 \mathrm{~km}$ (Huang et al. 2011b), which is consistent with this study. Guo et al. (2016) have processed a seismic profile OBS2013-1 located in the north of OBS2011-1 and found that the Moho is located at the depth of 23-27 km across the Xisha Islands. Gravity modelling results also show that the Moho depth is around 20-26 km in Xisha and Zhongsha Islands (Hao et al. 2011; Qin et al. 2011). Thus, thicknesses of more than $20 \mathrm{~km}$ were commonly observed for the crust beneath the reefs and islands in the NW margin. The model of Lü et al. (2017) also shows a much deeper Moho beneath the Zhongsha Trough than the flanks on both sides, which is opposite to the models of OBS-2014 and of this work. The depth differences of the Moho and mid-crustal boundary between Lü et al. (2017) and this work may come from the modelling strategy itself. The sediments also have a great influence on the crustal structures, which is modelled in more detail by constraining the velocity and depths of the interfaces in this work. In addition, the good fitting between the calculated and observed gravity anomaly in this work indicates a well-recovered crustal heterogeneity particularly across the rift and rigid blocks (Fig. 6a).

\subsection{Stretched crust and the failed rifts}

In order to provide information about the extension, the crustderived stretching factor $\beta$ is calculated for the Psw-profile based on the crustal thicknesses described above. The $\beta$ is the ratio between thicknesses of the stretched crust and the original crust. For calculating the whole crustal stretching factor $\left(\beta_{w c}\right.$; Figs $8 \mathrm{a}$ and $\left.\mathrm{b}\right)$, initial crustal thickness was set to $31 \mathrm{~km}$ according to the receiver function analyses in central Hainan Island (Huang et al. 2015). $\beta_{w c}$ ranges from 1.4 to 2.0 for the rigid blocks and increases to $\sim 2.5$ in the Zhongsha and Nansha Trough, which is quite similar with 

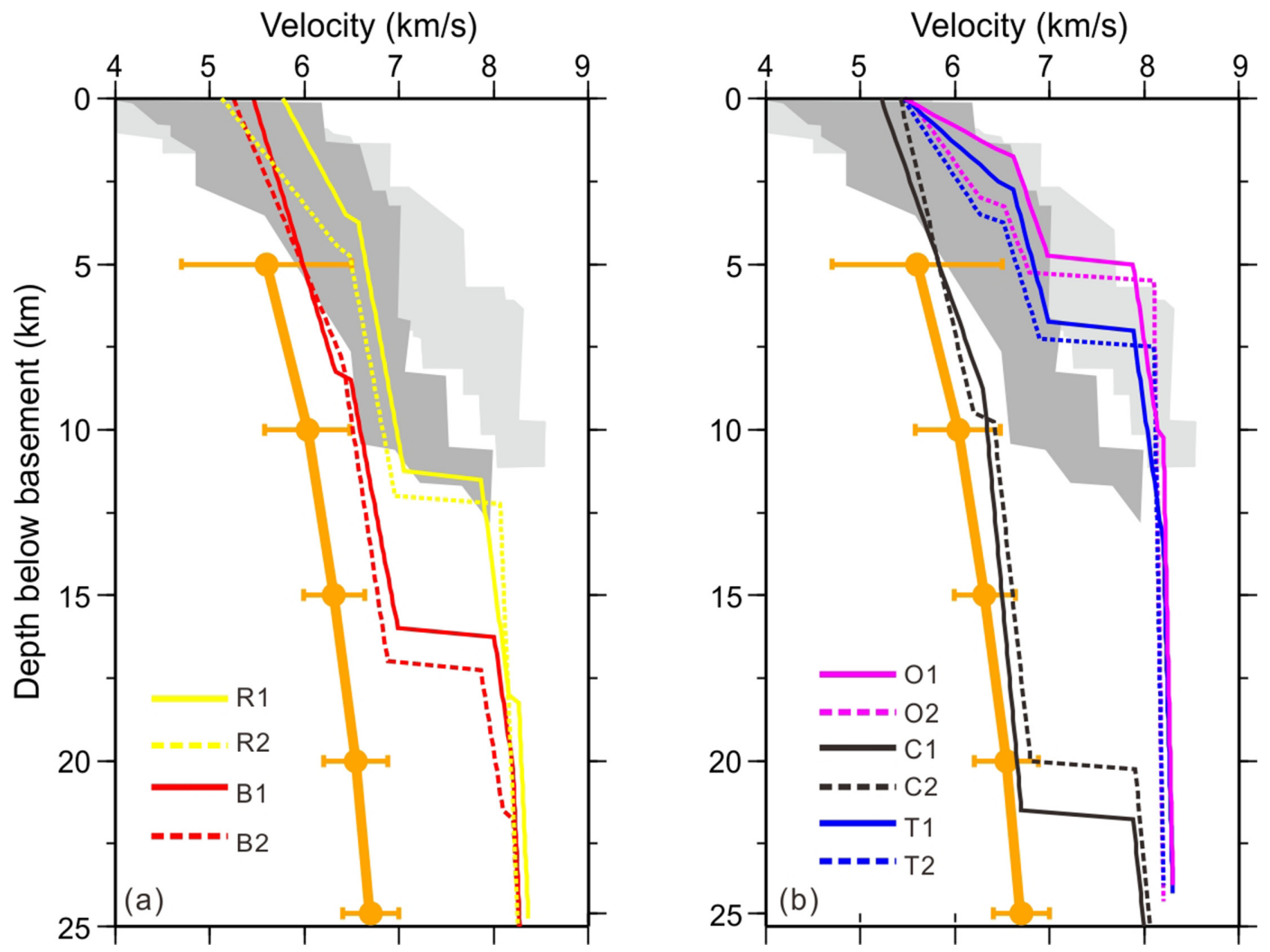

Figure 9. Velocity-depth profiles below the basement extracted from Psw. The locations are marked in Fig. 8(c) with vertical red arrows. The dark grey area represents a velocity compilation for transitional crust G8, the light grey area represents a compilation of Atlantic oceanic crust from (White et al. 1992), and the orange lines with uncertainty bars are average velocity for extended continental crust (Christensen \& Mooney 1995). Meaning of the model names: C, Continent; B, Block; R, Rift valley; T, Transition; O, Ocean.

the estimation in the Qiongdongnan Basin $(\sim 2.4$ in Zhang et al. 2012), but less than the value in the Xisha Trough ( $\sim 3.8$ based on crustal structures beneath OBS1996-4 in Fig. 2; Qiu et al. 2001). Lateral variation of the stretching factors reflects the progressive rift of the northern margins from east to west (Sun et al. 2009). Anyway, the crustal stretching in rifts of the NW and SW margin is much smaller compared to the NE margin where $\beta_{w c}$ reaches up to 6 or even higher in a failed rift centre (assuming $30 \mathrm{~km}$ as initial crustal thickness) proposed by McIntosh et al. (2014).

Supposing that the original thicknesses for the upper and lower crust are 15 and $16 \mathrm{~km}$ (McIntosh et al. 2014), stretching factors for the upper $\left(\beta_{u c}\right)$ and the lower crust $\left(\beta_{l c}\right)$ as well as the ratio between thicknesses of the upper crust and the lower crust $\left(T_{u c} / T_{l c}\right)$ can also be obtained (Figs $8 \mathrm{a}$ and $\mathrm{b}$ ). The results show that thicknesses of the upper and lower crust decrease by different amounts. The most striking discrepancy lies at the Zhongsha and Nansha Trough, where $\beta_{u c}$ reaches to $\sim 4.0$ and $\beta_{l c}$ remains at $\sim 2.0 . T_{u c} / T_{l c}$ drops quickly from the initial value $(\sim 0.94,15 \mathrm{~km} / 16 \mathrm{~km})$ on the NW flank of the Zhongsha Trough to as low as 0.5 in the SE (Fig. 8a) while the $\beta_{l c}$ shows a clear downtrend from $\sim 2.1$ to $\sim 1.8$, indicating a highly thinned upper crust and a slightly thickened lower crust (from $\sim 7.6$ to $\sim 8.9 \mathrm{~km}$ of the thickness, in Fig. $8 \mathrm{a}$ ). Similarly, higher $T_{u c} / T_{l c}$ $(\sim 1.4)$ and $\beta_{l c}(\sim 3.2)$ can be identified close to the OCT in the SW margin when compared to the conjugate region in the NW margin. By contrast, rigid blocks show a relatively uniform stretching for the upper $\left(\beta_{u c}=\sim 2.0\right)$ and lower crust $\left(\beta_{l c}=\sim 1.6\right.$, Figs $8 \mathrm{a}$ and b).

In general, the upper crust shows much more locally variable thicknesses than the lower crust. For comparison, McIntosh et al. (2014) found much higher thinning of the lower crust $\left(\beta_{u c}=\sim 1.0\right.$; $\left.\beta_{l c}=3.0-5.7\right)$ in the NE margin, especially towards the central basement high where a HVL is located and taken as post-rift underplating. The differences between $\beta$ in the northern margin represent a change in rheological behaviour of the ductile layers (Roy \& Royden 2000). A great loss of the lower crust in the NE margin, possibly in a way of large-scale seaward flowing, may provide spaces for the underplated material (McIntosh et al. 2014).

\subsection{Implications for the continental extension and opening of the SW Sub-basin}

Discrepancy of the stretching factor along the NW and NE margin reflect the differences in the style of extension from east to west ( $\mathrm{Li}$ et al. 2011). As demonstrated by crustal structures in the Psw-profile and the Xisha Trough (Qiu et al. 2001), the continental crust thins from south of Hainan to north end of the OCT in the NW margin over a distance of about $730 \mathrm{~km}$. The range of extension is nearly twice in the NW margin than in the NE margin $(\sim 425 \mathrm{~km})$ as expected by Hayes \& Nissen (2005). Meanwhile, the NW margin does not show any absence or extreme thinning of the lower crust. As suggested by numerical modelling (McKenzie et al. 2000; Roy \& Royden 2000), the ductile crust tends to smooth the crustal heterogeneity and broaden the deformation zone. It thus may have compensated loss of the deep crustal materials, leaving insufficient space for the corresponding decompression melting, for example the HVL. Since the rigid blocks show only weak and uniform deformation in response to the extension, it can also be seen as impedance for 

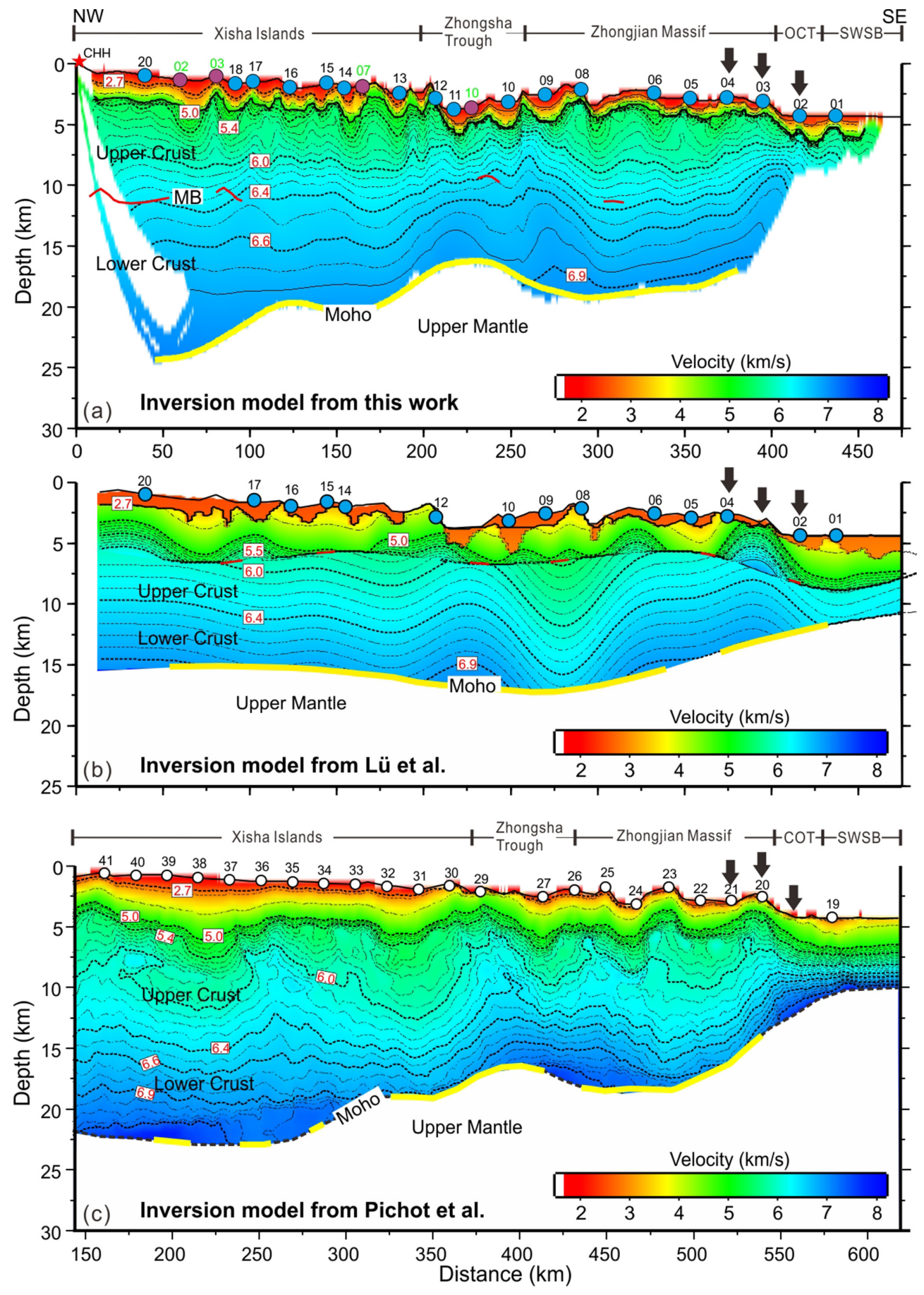

Figure 10. Comparison of the inversion velocity models. (a) Inversion model in this work. (b) Inversion model from Lü et al. (2017). (c) A segment of OBS-2014 and the location is shown by the yellow line in Fig. 2. Circles denote the OBSs used for modelling. Black arrows indicate the comparative points shown in Fig. 2. OCT, Ocean-Continent Transition zone; SWSB, Southwest Sub-basin; MB, mid-crustal boundary.

the ductile deformation and further development of the rift valleys (Courtillot 1982; Sun et al. 2009).

Rift basins in the SCS were mainly bounded by listric faults as shown in earlier reflection surveys (Ren et al. 2014). In the distal margins, detachment faults even sole into the middle or lower crust, forming a clear ductile boundary within the crust (Franke et al. 2014). In the Psw-profile, the highly stretched upper crust in the Zhongsha Trough indicates an asymmetrical rifting of the continental margin controlled by a low-angle fault (the $11^{\circ}$ slope in Fig. 5b). OBS-2014 also shows a clear discrepancy in horizontal extension accommodated by large-offset faults (Pichot et al. 2014). In addition, a narrow OCT $(\sim 25 \mathrm{~km})$ was revealed on the north of the deep basin in the Psw-profile, taking the submarine volcano at $\sim 430 \mathrm{~km}$ as the southern border where anomaly 6AA1 is indentified (Fig. 12a) (Barckhausen et al. 2014) and the slope at $\sim 405 \mathrm{~km}$ as the northern border (Figs $5 \mathrm{~b}$ and $8 \mathrm{c}$ ). From $605 \mathrm{~km}$ to the southern margin foot ( $\sim 655 \mathrm{~km}$ in Fig. $8 \mathrm{c})$, the basement has characteristics of the faulted blocks relative to the continental extension (Zhao 

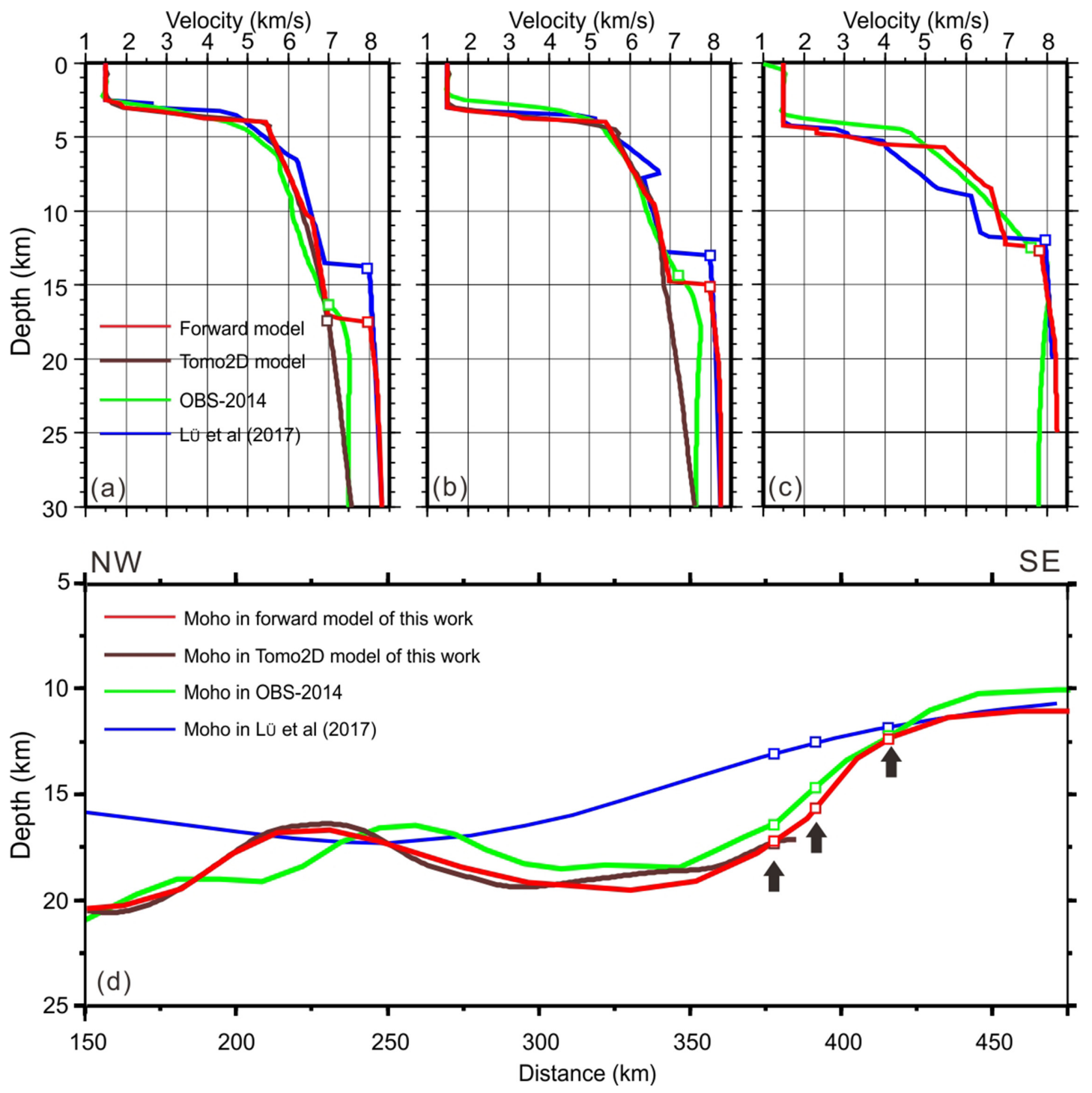

Figure 11. Comparison of the velocity-depth profiles. (a-c) The velocity-depth profiles at different locations; (d) depths of the Moho along the profiles. Black arrows denote the locations of the comparative points shown in Figs 2, 5and 10. Line-coloured boxes mark the depths of the Moho.

et al. 2011), where the velocity-depth profiles resemble the structure of OCT (Fig. 9b). Magnetic and gravity anomalies also show different characteristics between the oceanic basin and continental margins (Fig. 12). The identified OCTs on both margins generally correspond to negative gravity anomalies (Fig. 12b) (Gao et al. 2016) and have much narrower range in the NW margin than the SW margin of the SW Sub-basin, reflecting an asymmetrical geometry between the conjugate margins. Meanwhile, a major low-angle fault has been well revealed by the deep reflection survey along the SW margin (the location is seen in Fig. 12), which could lead to the higher $T_{u c} / T_{l c}$ and $\beta_{l c}$ on the SW side close to the OCT. Thus, major low-angle faults played a similar role in forming the rift valley (Zhongsha Trough) and the OCT, which indicates a common mechanism for the crustal deformation along the margins of the SW Sub-basin (Fig. 13).

Asymmetry of the conjugate margins was also found in other places, for example the Gulf of Lions (Lepretre et al. 2013), IberiaNewfoundland margins (Reston 2009) and Labrador Sea conjugate margins (Chian et al. 1995). By comparison with the Gulf of Lions (Fig. 14, Lepretre et al. 2013) which formed in a backarc setting, it is clear that the zones of crustal thinning (e.g. OCT) along both margins are much narrower as compared to the over $150 \mathrm{~km}$ width of these zones commonly revealed at ocean basins, such as the Atlantic Ocean (e.g. Biari et al. 2017). The crustal thicknesses vary across both the SCS and Gulf of Lions margin pairs, where the side at which oceanic crust subducted is thinner (Fig. 14). This might be due to erosion of the crustal layers due to the subduction process itself. The Moho depth variations at the margin side with larger crustal thickness are prominent but seem to be less repeated along the normally rifted margins. In addition, the thinner oceanic crusts $(\sim 5 \mathrm{~km})$ in the Gulf of Lions as well as in the SW Sub-basin are typical for a backarc basin setting (Louden 1980), and different from the typical Atlantic oceanic crust $(\sim 7.2 \mathrm{~km})$. Together the above observations suggest a more 'unstable' rifting processes with many rifts opening and closing, which can be contributed to the heterogeneous influence from the subducted slabs (Gailler et al. 2009). However, effects from tectonic heritage e.g. mantle plume (Zhang et al. 2018), collision-related suture zones (Brune et al. 2014) and rigid blocks (Courtillot 1982) cannot be ignored. 

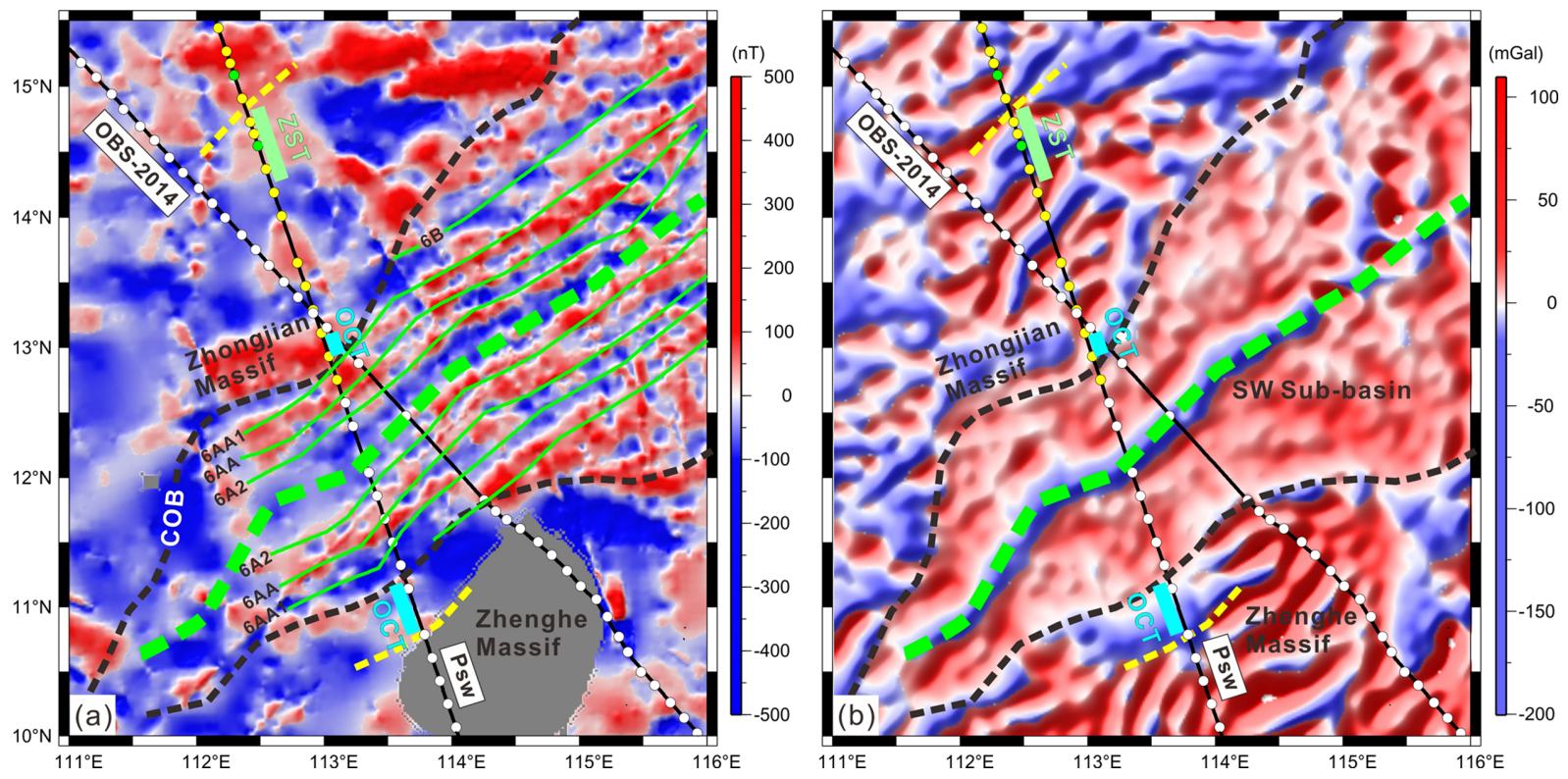

Figure 12. Magnetic and gravity anomaly around the SW sub-basin. (a) Magnetic anomaly map. Green lines are interpreted anomalies from (Barckhausen et al. 2014). Circles are OBSs in OBS2011-1, OBS2009-1 and OBS-2014. Cyan thick lines are the OCT identified in this work. Bold green dash line is the abandoned spreading ridge. Yellow dash lines are the two major low-angle faults identified from velocity model of OBS2011-1 and the MCS data (Ding et al. 2016). (b) Gravity anomaly map. ZST, Zhongsha Trough; COB, continent-ocean boundary; OCT, Ocean-Continent Transition zone.

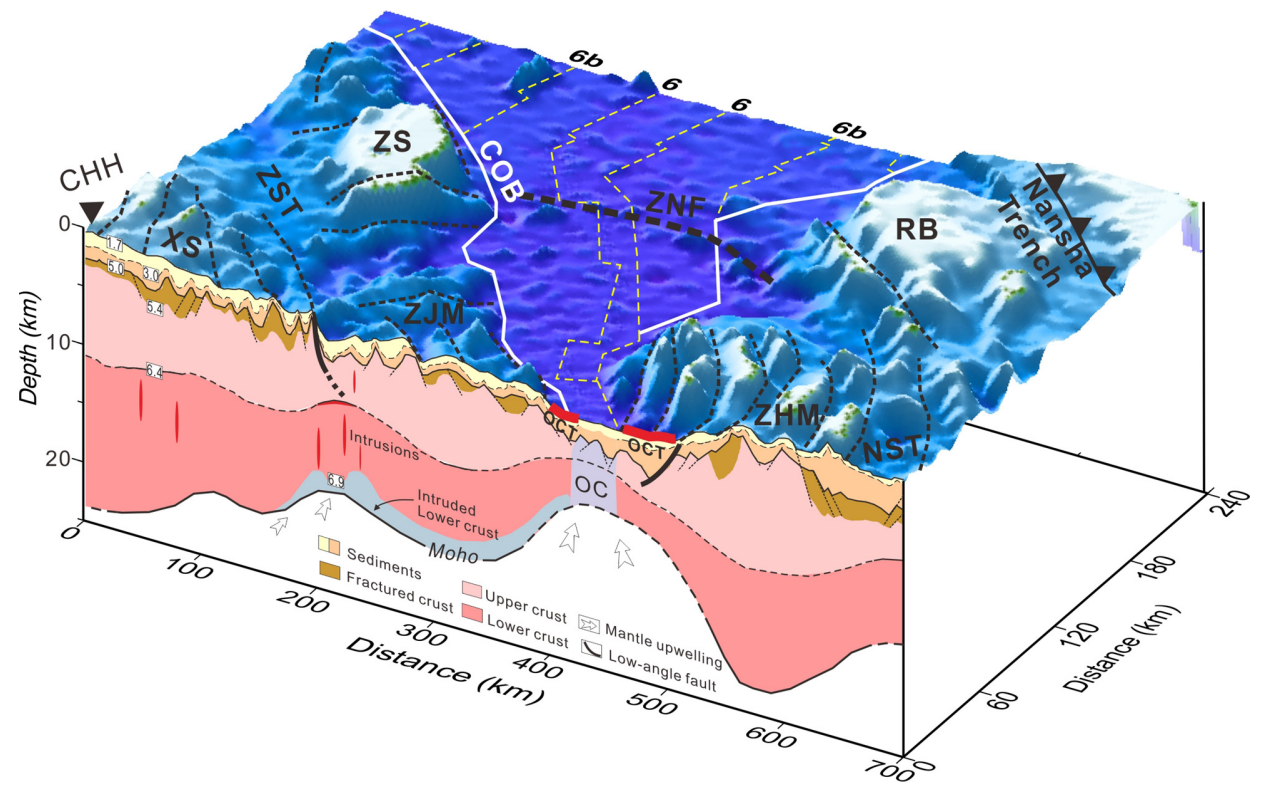

Figure 13. Pre-spreading crustal structure and geological interpretation along the Psw reconstructed to $\sim 20 \mathrm{Ma}$, with reconstruction geometries extracted from GPlates (Boyden et al. 2011). Yellow broken lines mark the magnetic stripes. The velocity contours are labeled in white boxes, among which the contour of $6.9 \mathrm{~km} \mathrm{~s}^{-1}$ limits the top of the intruded lower crust. ZST, Zhongsha Trough; XS, Xisha Islands; CHH, Chenhang Island; ZJM, Zhongjian Massif; ZHM, Zhenghe Massif; RB, Reed Bank; ZNF, Zhongnan Transform Fault; NST, Nansha Trough.

\section{CONCLUSIONS}

Wide-angle refraction seismic data in Xisha Islands provide detailed velocity model in the NW margin of the SCS. A long profile of the crustal structure spanning the SCS was built up for comparison of the conjugate margins. The crustal structure shows lateral variations along the continental margins, in which the crustal thickness decreases from $\sim 22 \mathrm{~km}$ in the Xisha Islands to only $\sim 5 \mathrm{~km}$ in the deep basin. The upper crust shows nearly two times of the stretching factor than the lower crust across the Zhongsha Trough. Whereas in the rigid blocks, the stretching is uniform, which is distinct from the NE margin, where the thinning of the lower crust is much higher. An asymmetrical thickening and velocity increase of $\sim 0.3 \mathrm{~km} \mathrm{~s}^{-1}$ of the middle and lower crust is found in the Zhongsha Trough, corresponding to the highly thinned upper crust. The OCT also shows asymmetry in width, which is much wider in the southern part where a notable listric detachment fault is interpreted.

Major low-angle fault constraint rifting and an asymmetrical conjugate pattern of the SW Sub-basin can be proposed and characterized with highly thinned upper crust and the corresponding uplifted 

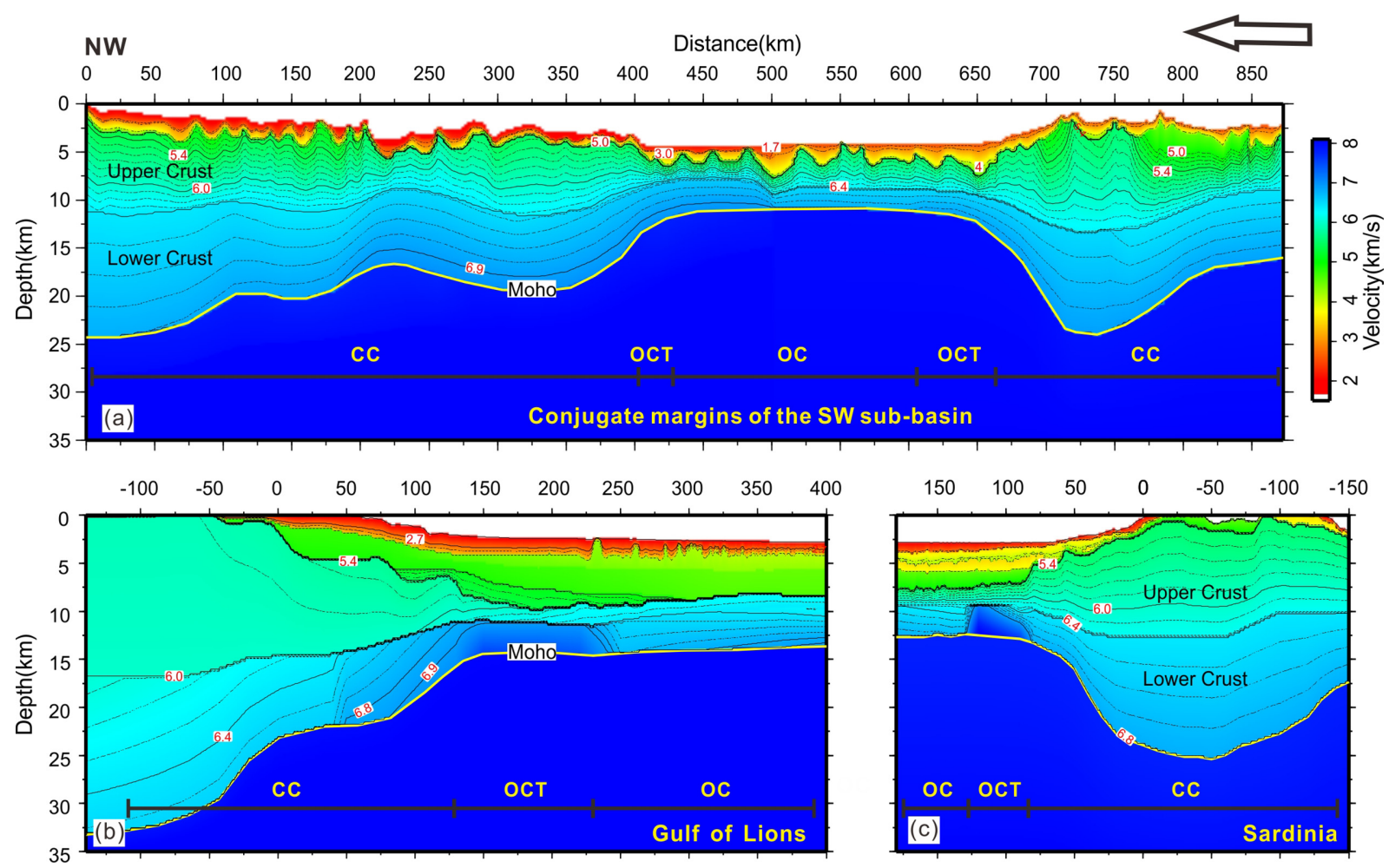

Figure 14. Comparison of the deep structure between the SCS and the Gulf of Lions margins. (a) The SW Sub-basin margins in the SCS; (b and c) the conjugate Gulf of Lions-West Sardinia margins (Lepretre et al. 2013). The arrow denotes direction of the proto-subduction. CC, Continental Crust; OC, Oceanic Crust; OCT, Ocean-Continent Transition zone.

middle-lower crust across the rift centers. The rigid blocks may also act as a kind of impedance for further evolution of the failed rifts and affected the shaping of the OCT.

\section{ACKNOWLEDGEMENTS}

We thank the scientific teams of the cruises and the crew of the R/V Shiyan 2. The National Natural Science Foundation of China (41676045, 41674092, 41306046, 41476033 and 41730532), the Guangdong NSF research team project (2017A030312002) and the Project of Geological and Geophysical Series Maps of China (GZH200900504) financially supported this study. The GMT software (Wessel \& Smith 1995) and Seismic Unix software package (Stockwell 1999) were used to plot several figures. We thank Weijian Hu and Xiaoran Guo for their help on the gravity modelling and the data processing. We thank Marc-André Gutscher for improving the language of this manuscript. We would like to thank Xiaodong Wei and Xiujuan Wang and the editor for thorough reviews that substantially improved the quality of the manuscript. Supporting data are included as Table S1 and Fig. S1; any additional data presented in this study can be obtained from Haibo Huang (e-mail: go223@scsio.ac.cn).

\section{REFERENCES}

Barckhausen, U., Engels, M., Franke, D., Ladage, S. \& Pubellier, M., 2014. Evolution of the South China Sea: Revised ages for breakup and seafloor spreading, Mar. Pet. Geol., 58, 599-611.

Biari, Y. et al. 2017. Opening of the central Atlantic Ocean: Implications for geometric rifting and asymmetric initial seafloor spreading after continental breakup, Tectonics, 36, 1129-1150.
Boyden, J.A. et al., 2011. Next-generation plate-tectonic reconstructions using GPlates, Geoinformatics: Cyber infrastructure for the Solid Earth Sciences, 7, 95-114, eds. Keller, G.R. \& Baru, C., Cambridge University Press.

Briais, A., Partriat, P. \& Tapponnier, P., 1993. Updated interpretation of magnetic anomalies and seafloor spreading in the South China Sea: implications for the Tertiary Tectonics of Southeast Asia, J. geophys. Res., 98(B4), 6299-6328.

Brune, S., Heine, C., Perez-Gussinye, M. \& Sobolev, S.V., 2014. Rift migration explains continental margin asymmetry and crustal hyper-extension, Nat. Commun., 5, 4014-4023.

Chen, D.H., Jiang, S.Y. \& Liu, J., 2005. Geochemical characteristics and sedimentary environment of surface sediments from Xisha Trough, Mar. Geol. Quater. Geol., 25(2), 37-43.

Chian, D., Louden, K.E. \& Reid, I., 1995. Crustal structure of the Labrador Sea conjugate margin and implications for the formation of nonvolcanic continental margins, J. geophys. Res., 100(12), 24 239-24 253.

Christensen, N.I. \& Mooney, W.D., 1995. Seismic velocity structure and composition of the continental-crust—a global view, J. geophys. Res. 100(B6), 9761-9788.

Courtillot, V., 1982. Propagating rifts and continental breakup, Tectonics, 1(3), 239-250.

Dean, S.M., Minshull, T.A., Whitmarsh, R.B. \& Louden, K.E., 2000. Deep structure of the ocean-continent transition in the southern Iberia Abyssal Plain from seismic refraction profiles: the IAM-9 transect at $4020^{\prime} \mathrm{N}, J$. geophys. Res., 105(B3), 5859-5885.

Ding, W.W., Li, J.B. \& Clift, P.D., 2016. Spreading dynamics and sedimentary process of the Southwest Sub-basin, South China Sea: constraints from multi-channel seismic data and IODP Expedition 349, J. Asian Earth Sci., 115, 97-113.

Ding, W.W., Schnabel, M., Franke, D., Ruan, A.G. \& Wu, Z.L., 2012. Crustal structure across the Northwestern Margin of South China Sea: evidence for magma-poor rifting from a wide-angle seismic profile, Acta Geol. Sin., 86(4), 854-866. 
Flower, M.F.J., Tamaki, K. \& Hoang, N., 1998. Mantle extrusion: a model for dispersed volcanism and DUPAL-like asthenosphere in east Asia and the western Pacific, Flower, M.F.J., Chun, S.L. \& Lo, C.H.. Mantle Dynamics and Plate Interactions in East Asia, 27, AGU, U.S.A, p. 67-88.

Franke, D., Savva, D., Pubellier, M., Steuer, S., Mouly, B., Auxietre, J.L., Meresse, F. \& Chamot-Rooke, N., 2014. The final rifting evolution in the South China Sea, Mar. Pet. Geol., 58(2014), 704-720.

Funck, T., Jackson, H.R., Louden, K.E., Dehler, S.A. \& Wu, Y., 2004. Crustal structure of the northern Nova Scotia rifted continental margin (eastern Canada), J. geophys. Res., 109(B9), doi:10.1029/2004JB003008.

Gailler, A., Klingelhoefer, F., Olivet, J.L. \& Aslanian, D., 2009. Crustal structure of a young margin pair: new results across the Liguro-Provencal basin from wide-angle seismic tomography, Earth planet. Sci. Lett., 286(1-2), 333-345.

Gao, J.W., Wu, S.G., McIntosh, K., Mi, L.J., Liu, Z. \& Spence, G., 2016. Crustal structure and extension mode in the northwestern margin of the South China Sea, Geochem. Geophys. Geosyst., 17, 2143-2167.

Guo, X.R., Zhao, M.H., Huang, H.B., Qiu, X.L., Wang, J., He, E.Y. \& Zhang, J.Z., 2016. Crustal structure of Xisha block and its tectonic attributes, Chin. J. Geophys., 59(4), 1414-1425.

Hao, T.Y. et al., 2011. Integrated geophysical research on the tectonic attribute of conjugate continental margin of South China Sea, Chin. J. Geophys., 54(12), 3098-3116.

Nissen, S.S., Hayes, D.E. \& Yao, B., 1995. Gravity heat flow, and seismic constraints on the processes of crustal extension: Northern margin of the South China Sea, J. geophys. Res.. 100(B11), 22447-22483.

.Hayes, D.E \& Nissen, S.S., 2005. The South China Sea margins: implications for rifting contrasts, Earth planet. Sci. Lett., 237, 601-616.

He, E.Y., Zhao, M.H., Qiu, X.L., Sibuet, J.C., Wang, J. \& Zhang, J.Z., 2016. Crustal structure across the post-spreading magmatic ridge of the East sub-basin in the South China Sea: tectonic significance, J. Asian Earth Sci., 121(2016), 139-152.

Holloway, N.H., 1982. The North Palawan block, Philippines: its relation to the Asian mainland and its role in the evolution of the South China Sea, Am. Assoc. Petrol. Geol. Bull., 66(9), 1355-1383.

Huang, H.B., Qiu, X.L., Xu, H.L., Zhao, M.H., Hao, T.Y., Xu, Y. \& Li, J.B., 2011a. Preliminary results of the earthquake observation and the onshore offshore seismic experiments on Xisha Block, Chin. J. Geophys., 54(12), 3161-3170.

Huang, H.B., Qiu, X.L., Xu, Y. \& Zeng, G.P., 2011b. Crustal structure beneath the Xisha Islands of the South China Sea simulated by the teleseismic receiver function method, Chin. J. Geophys., 54(11), 2788-2798.

Huang, H.B., Tosi, H., Chang, S.J., Xia, S.H. \& Qiu, X.L., 2015. Receiver function imaging of the mantle transition zone beneath the South China Block, Geochem. Geophys. Geosyst., 16(10), 3666-3678.

Huismans, R.S. \& Beaumont, C., 2014. Rifted continental margins: The case for depth-dependent extension, Earth and Planetary Science Letters, 407(8), 148-162.

Korenaga, J., Holbrook, W.S., Detrick, R.S. \& Kelemen, P.B., 2001. Gravity anomalies and crustal structure at the southeast Greenland margin, $J$. geophys. Res., 106(B5), 8853-8870.

Korenaga, J., Holbrook, W.S., Kent, G.M., Kelemen, P.B., Detrick, R.S., Larsen, H.C., Hopper, J. R. \& Dahl-Jensen, T., 2000. Crustal structure of the Southeast Greenland margin from joint refraction and reflection seismic tomography, J. geophys. Res.. 105(B9), 21 591-21 614.

Larsen, H.C. et al., 2018. Rapid transition from continental breakup to igneous oceanic crust in the South China Sea, Nat. Geosci., 11, 782-789.

Lepretre, A., Klingelhoefer, F., Graindorge, D., Schnurle, P., Beslier, M.O., Yelles, K., Deverchere, J. \& Bracene, R., 2013. Multiphased tectonic evolution of the Central Algerian margin from combined wide-angle and reflection seismic data off Tipaza, Algeria, J. geophys. Res., 118(B8), 3899-3916.

Li, C.F. et al., 2014a. Ages and magnetic structures of the South China Sea constrained by deep tow magnetic surveys and IODP Expedition 349, Geochem. Geophys. Geosyst., 15(12), 4958-4983.

Li, J.B., Ding, W.W., Gao, J.Y., Wu, Z.Y. \& Zhang, J., 2011. Cenozoic evolution model of the sea floor spreading in South China Sea: new constraints from high resolution geophysical data, Chin. J. Geophys., 54(12), 3004-3015.

Li, L., Clift, P.D., Stephenson, R. \& Nguyen, H.T., 2014b. Non-uniform hyper-extension in advance of seafloor spreading on the Vietnam continental margin and the SW South China Sea, Basin Res., 26(1), 106-134.

Lister, G.S., Etheridge, M.A. \& Symonds, P.A., 1986. Detachment faulting and the evolution of passive continental margins, Geology, 14(3), 246250.

Louden K.E., 1980, The crustal and lithospheric thicknesses of the Philippine Sea as compared to the Pacific, Earth and Planetary Science Letters. , 50(1), 275-288.

Lü, C.C., Hao, T.Y., Lin, J. \& Qiu, X.L., 2017. The role of rifting in the development of the continental margins of the Southwest subbasin, South China Sea: insights from an OBS experiment, Mar. Geophys. Res., 38(12), 105-123.

Ma, Y.B., Wu, S.G., Gu, M.F., Lu, Y.T., Dong, D.D. \& Zhao, H.T., 2010. Seismic reflection characteristics and depositional model of carbonate platforms in Xisha sea area, Acta Oceanolog. Sin., 32(4), 118-128.

McIntosh, K., Lavier, L., van Avendonk, H., Lester, R., Eakin, D. \& Liu, C.S., 2014. Crustal structure and inferred rifting processes in the northeast South China Sea, Mar. Pet. Geol., 58, 612-626.

McKenzie, D., Nimmo, F., Jackson, J.A., Gans, P.B. \& Miller, E.L., 2000. Characteristics and consequences of flow in the lower crust, J. geophys. Res., 105(B5), 11029-11046.

Petersen, K.D. \& Schiffer, C., 2016. Wilson cycle passive margins: control of orogenic inheritance on continental breakup, Gondwana Res., 39, 131144.

Pichot, T., Delescluse, M., Chamot-Rooke, N., Pubellier, M., Qiu, Y. \& Meresse, F., 2014. Deep crustal structure of the conjugate margins of the SW South China Sea from wide-angle refraction seismic data, Mar. Pet. Geol., 58, 627-643.

Qin, J.X., Hao, T.Y., Xu, Y., Huang, S., Lü, C.C. \& Hu, W.J., 2011. The distribution characteristics and the relationship between the tectonic units of the Moho depth in South China Sea and adjacent areas, Chin. J. Geophys., 54(12), 3171-3183.

Qiu, N., Wang, Z.F., Xie, H., Sun, Z.P., Wang, Z.W., Sun, Z. \& Zhou, D., 2013. Geophysical investigations of crust-scale structural model of the Qiongdongnan Basin, Northern South China Sea, Mar. Geophys. Res., 34(3-4), 259-279.

Qiu, X.L., Ye, S.Y., Wu, S.M., Shi, X.B., Zhou, D., Xia, K.Y. \& Flueh, E.R., 2001. Crustal structure across the Xisha Trough, northwestern South China Sea, Tectonophysics, 341(1-4), 179-193.

Qiu, X.L., Zhao, M.H., Ao, W., Lv, C.C., Hao, T.Y., You, Q.Y., Ruan, A.-G. \& Li, J.-B., 2011. OBS survey and crustal structure of the Southwest Subbasin and Nansha Block, South China Sea, Chin. J. Geophys., 54(12), 3117-3128.

Ren, J.Y. et al., 2014. Characterizing the nature, evolution and origin of detachment fault in central depression belt, Qiongdongnan Basin of South China Sea: evidence from seismic reflection data, Acta Oceanolog. Sin., 33(2), 118-126

Reston, T.J., 2009. The structure, evolution and symmetry of the magmapoor rifted margins of the North and Central Atlantic: a synthesis, Tectonophysics, 468(1-4), 6-27.

Roy, M. \& Royden, L.H., 2000. Crustal rheology and faulting at strikeslip plate boundaries 2. Effects of lower crustal flow, J. geophys. Res., 105(B3), 5599-5613.

Sandwell, D.T. \& Smith, W.H.F., 2009. Global marine gravity from retracked Geosat and ERS-1 altimetry: ridge segmentation versus spreading rate, $J$. geophys. Res., 114(B1).

Sibuet, J.C., Yeh, Y.C. \& Lee, C.S., 2016. Geodynamics of the South China Sea, Tectonophysics, 692(B5), 98-119.

Stockwell, J.W., 1999. The CWP/SU: seismic Un*x package, Comput. Geosci., 25(4), 415-419.

Sun, W.D., 2016. Initiation and evolution of the South China Sea: an overview, Acta Geochim., 35(3), 215-225.

Sun, Z., Zhong, Z.H., Keep, M., Zhou, D., Cai, D.S., Li, X.S. \& Wu, S.M., 2009. 3D analogue modeling of the South China Sea: a discussion on breakup pattern, J. Asian Earth Sci., 34(4), 544-556. 
Tapponnier, P. \& Peltzer, G., 1982. Propagating extrusion tectonics in Asia: new insights from simple experiments with plasticine, Geology, 10(12), 611-616.

Taylor, B. \& Hayes, D.E., 1983. Origin and history of the South China Sea basin, in The Tectonic And Geologic Evolution of Southeast Asia Seas and Islands, pp. 23-56, ed. Hayes, D.E., Geophysical Monograph.

Thybo, H. \& Nielsen, C.A., 2009. Magma-compensated crustal thinning in continental rift zones, Nature, 457(7231), 873-876.

Wang, Q., Qiu, X.L., Zhao, M.H., Huang, H.B. \& Ao, W., 2016. Analysis and processing on abnormal OBS data in the South China Sea, Chin. J. Geophys., 59(3), 1102-1112.

Wang, T.K., Chen, M.K., Lee, C.S. \& Xia, K., 2006. Seismic imaging of the transitional crust across the northeastern margin of the South China Sea, Tectonophysics, 412(3-4), 237-254.

Wei, X.D., Zhao, M.H., Ruan, A.G., Qiu, X.L., Hao, T.Y., Wu, Z.L., Ao, W. \& Xiong, H., 2011. Crustal structure of shear waves and its tectonic significance in the mid northern continental margin of the South China Sea, Chin. J. Geophys., 54(12), 3150-3160.

Wessel, P. \& Smith, W.H., 1995. New version of the generic mapping tools, EOS, Trans. Am. Geophys. Un., 76, 329.

West, M., Menke, W., Tolstoy, M., Webb, S. \& Sohn, R., 2001. Magma storage beneath axial volcano on the Juan de Fuca mid-ocean ridge, Nature, 413(6858), 833-836.

White, R.S., Mckenzie, D. \& Onions, R.K., 1992. Oceanic crustal thickness from seismic measurements and rare-earth element inversions, J. geophys. Res., 97(B13), 19683-19715.

Wu, S.M., Yang, T., Zhou, D., Qiu, X.L. \& Xia, B., 2005. Discussion on the extension model for the conjugate continental margin of South China Sea, Geol. J. China Univ., 11(1), 105-110.

Wu, Z.L., Li, J.B., Ruan, A.G., Lou, H., Ding, W.W., Niu, X.W. \& Li, X.B., 2011. Crustal structure of the northwestern sub-basin, South China Sea: results from a wide-angle seismic experiment, Sci. China Earth Sci., 41(10), 1463-1476.

Yan, P., Zhou, D. \& Liu, Z.S., 2001. A crust structure profile across the northern continental margin of the South China Sea, Tectonophysics, 338(1), 1-21.
Yan, Q.S., Shi, X.F., Liu, J.H. \& Chen, D.G., 2007. Characteristics of volcanic ash in surface sediments around Zhongsha Islands: response to tectonic setting in the north margin of the South China Sea, Mar. Geol. Quater. Geol., 27(4), 9-16.

Yu, Z.T., Li, J.B., Ding, W.W., Zhang, J., Ruan, A.G. \& Niu, X.W., 2017. Crustal structure of the Southwest Subbasin, South China Sea, from wideangle seismic tomography and seismic reflection imaging, Mar. Geophys. Res., 38(1-2), 85-104.

Zelt, C.A., 1999. Modeling strategies and model assessment for wide-angle seismic traveltime data, Geophys. J. Int., 139(1), 183-204.

Zelt, C.A. \& Smith, R.B., 1992. Seismic traveltime inversion for 2-D crustal velocity structure, Geophys. J. Int., 108(1), 16-34.

Zhang, G.L., Luo, Q., Zhao, J., Jackson, M.G. \& Guo, L.S., 2018. Geochemical nature of sub-ridge mantle and opening dynamics of the South China Sea, Earth planet. Sci. Lett., 489(2018),145-155.

Zhang, Y.F., Hu, D.K., Wang, W.Y., Qiu, Z.Y. \& Li, F.C., 2012. A comparison of crustal stretching characteristics between northern and southern slopes of the South China Sea, J. Tropical Oceanogr., 31(3), 137-143.

Zhao, C.Y., Song, H.B., Li, J.B., Song, Y. \& Tian, L.H., 2011. Tectonic and seismic interpretation of line NH973-1 along southwest sub-basin in South China Sea, Chin. J. Geophys., 54(12), 3258-3268.

Zhou, D., Ru, K. \& Chen, H.Z., 1995. Kinematics of Cenozoic extension on the South China Sea continental margin and its implications for the tectonic evolution of the region, Tectonophysics, 251(1-4), 161-177.

\section{SUPPORTING INFORMATION}

Supplementary data are available at $G J I$ online.

Figure S1. Examples of the PcP phases for velocity modelling. Table S1. $\chi^{2}$ values for all phases used in the forward modelling of each OBS.

Please note: Oxford University Press is not responsible for the content or functionality of any supporting materials supplied by the authors. Any queries (other than missing material) should be directed to the corresponding author for the paper. 